\title{
Stereoselective synthesis of 1-deoxynojirimycin, D-glucono- $\delta$-lactam and D-altrono- $\delta$-lactam from a common chiral intermediate derived from D-mannitol
}

\author{
Mettu Ravinder, ${ }^{*}$ Thatikonda Narendar Reddy, Budde Mahendar, \\ and Vaidya Jayathirtha Rao* \\ Crop Protection Chemicals Division, Indian Institute of Chemical Technology, Uppal Road \\ Tarnaka, Hyderabad 500 607, India \\ \$Present address: Genomics Research Center, Academia Sinica, 128 Academia Road, Section 2, \\ Nankang, Taipei 115, Taiwan (ROC) \\ E-mail: ravi_iictindia@yahoo.co.in; jrao@iict.res.in
}

\begin{abstract}
A stereoselective synthesis of 1-deoxynojirimycin, D-glucono- $\delta$-lactam and D-altrono- $\delta$-lactam were accomplished from a common chiral intermediate derived from D-mannitol. The key transformations in the synthesis include Miyashita C-2 selective endo-mode azide opening of epoxy alcohol and Sharpless asymmetric dihydroxylation.
\end{abstract}

Keywords: Epoxidation, dihydroxylation, diastereoselectivity, cyclization, azasugars

\section{Introduction}

Polyhydroxylated piperidines and their derivatives commonly known as azasugars or iminosugars are of great interest in synthetic organic chemistry, bio-chemistry, and pharmacology due to their extraordinary biological properties. ${ }^{1}$ A large number of azasugars have been extracted from natural sources, mainly from plants, microorganisms and more recently from insects and sea sponges. ${ }^{2}$ Among the azasugars, naturally occurring 1-deoxy-azasugars and their analogues such as deoxynojirimycin 1 (DNJ), deoxymannojirimycin 2 (DMJ), adenophorine $\mathbf{3}$, fagomine 4 and D-glucono- $\delta$-lactam 5 (Figure 1) are the structural analogues of pyranose carbohydrates in which the ring oxygen atom is replaced by a nitrogen atom have been found to act as potent glycosidase and glycosyl transferase inhibitors. ${ }^{3}$ Moreover these 1-deoxy-azasugars are used as therapeutic agents for the treatment of various conditions such as cancer, HIV infection, hepatitis $\mathrm{C}$ virus infection, diabetes, influenza viral infection, and other carbohydrate related metabolic disorders. ${ }^{4}$ Synthetic 1 -deoxynojirimycin derivatives such as $N$-hydroxyethyl- 
DNJ 7 (Miglitol or Glyset) and $N$-butyl-DNJ 8 (Zavesca) have been already approved for the treatment of non-insulin-dependent diabetes and Gaucher's disease respectively. ${ }^{5}$<smiles>OC[C@H]1NC[C@@H](O)[C@H](O)[C@@H]1O</smiles>

1

1-Deoxynojirimycin (DNJ)<smiles>O=C1N[C@H](CO)[C@@H](O)[C@H](O)[C@H]1O</smiles>

5

D-Glucono- $\delta$-lactam<smiles>OC[C@H]1NC[C@@H](O)[C@H](O)[C@H]1O</smiles>

2

1-Deoxymannojirimycin<smiles>O=C1N[C@H](CO)[C@@H](O)[C@H](O)[C@H]1O</smiles>

6<smiles>OC[C@H]1N[C@H](CO)[C@@H](O)[C@H](O)[C@H]1O</smiles>

3

Adenophorine<smiles>OCCN1C[C@H](O)[C@@H](O)[C@H](O)[C@H]1CO</smiles>

N-Hydroxy ethyl DNJ (Miglitol)<smiles>OC[C@H]1NCC[C@@H](O)[C@@H]1O</smiles>

4

Fagomine<smiles>OC[C@@H]1[C@H](O)N(Cc2ccccc2)C[C@H](O)[C@@H]1O</smiles>

8

N-Butyl DNJ

(Zavesca)

Figure 1. Some polyhydroxypiperidines.

At present there are about 35 natural azasugars that act as glycosidase inhibitors; however, their isolation in the pure form from natural sources is a laborious and expensive exercise. Although a number of synthetic routes to azasugars are published to date, development of new synthetic strategy for the synthesis of natural as well as unnatural azasugars from easily available starting materials with high level of stereocontrol is always in demand in organic chemistry. ${ }^{6}$ In continuation of our research on the synthesis of $N$-heterocyclic compounds ${ }^{7}$ and natural products, ${ }^{8}$ herein we describe an efficient synthetic approach to the stereoselective synthesis of 1-deoxynojirimycin (1), as well as its analogues D-glucono- $\delta$-lactam (5) and D-altrono- $\delta$-lactam (6) in good yield from a common chiral intermediate derived from the inexpensive starting material D-mannitol.

\section{Results and Discussion}

A retrosynthetic analysis for the synthesis of targeted azasugars is shown in Scheme 1. The target molecules 1, 5 and $\mathbf{6}$ were envisioned to be obtained from the common chiral intermediate $\mathbf{1 0}$ that could be derived from 9 through regioselective epoxide opening with azide nucleophile and Wittig olefination as key steps. The epoxy alcohol 9 could be obtained from D-mannitol via cyclohexylidene D-glyceraldehyde. 
<smiles>[X]C1=C([R2])C([R2])([R])[C@@H](O)[C@@H](CO)N1</smiles>

1. $\mathrm{R}, \mathrm{R}^{3}=\mathrm{H}, \mathrm{R}^{1}, \mathrm{R}^{2}=\mathrm{OH} ; \mathrm{X}=2 \mathrm{H}$

5. $R, R^{3}=H, R^{1}, R^{2}=O H ; X=O$

6. $\mathrm{R}, \mathrm{R}^{3}=\mathrm{OH}, \mathrm{R}^{1}, \mathrm{R}^{2}=\mathrm{H}, \mathrm{X}=\mathrm{O}$

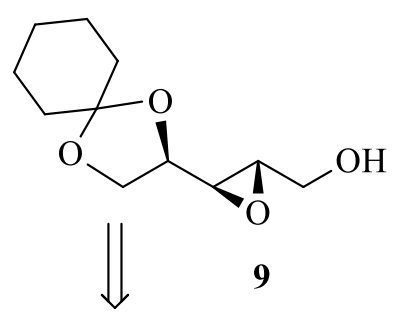

D-Mannitol

Scheme 1. Retrosynthetic plan for the synthesis of the title compounds $\mathbf{1 , 5}$ and $\mathbf{6}$.

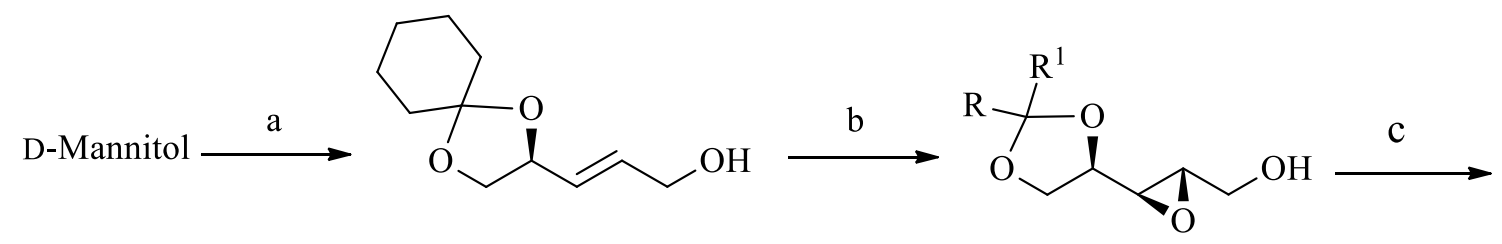

11

9

$\mathrm{R}=\mathrm{R}^{1}=-\left(\mathrm{CH}_{2}\right)_{5^{-}}$<smiles>[R]C1([R])OC[C@@H]([C@H](O)[C@H](N)CO)O1</smiles>

12

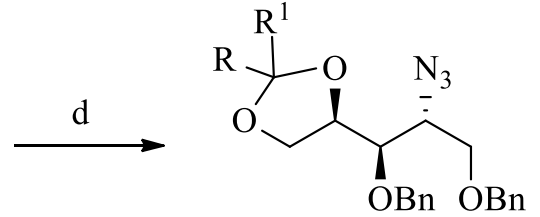

13

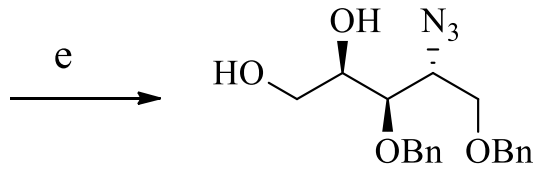

14<smiles>CCOC(=O)C=C[C@H](OCCc1ccccc1)[C@H](C)CCc1ccccc1</smiles>

10

Reagents and conditions: (a) ref. 9; (b) diethyl L-tartrate, $\mathrm{Ti}\left(\mathrm{O}^{i} \mathrm{Pr}\right)_{4}$, cumene hydroperoxide, $4 \AA$ MS, DCM, $-20{ }^{\circ} \mathrm{C}, 72 \mathrm{~h}, 93 \%, 94 \%$ de; (c) (MeO) 3 B, NaN 3 , DMF, $50{ }^{\circ} \mathrm{C}, 6 \mathrm{~h}$, then $\mathrm{NaIO}_{4}, 95 \%$; (d) benzyl bromide, $\mathrm{NaH}$, THF, $n$-Bu 4 NI, $0{ }^{\circ} \mathrm{C}$-rt, 16 h, 94\%; (e) $10 \% \mathrm{HCl}, \mathrm{CH}_{3} \mathrm{CN}, \mathrm{rt}, 4 \mathrm{~h}, 95 \%$; (f) (i) $\mathrm{NaIO}_{4}$, aq. $\mathrm{CH}_{3} \mathrm{CN}(60 \%)$, rt, $30 \mathrm{~min}$, quantitative; (ii) (EtO) ${ }_{2} \mathrm{P}(\mathrm{O}) \mathrm{CH}_{2} \mathrm{CO}_{2} \mathrm{Et}, \mathrm{LiCl}$, $\left({ }^{i} \mathrm{Pr}\right)_{2} \mathrm{NEt}, \mathrm{CH}_{3} \mathrm{CN}$, rt, 24 h, 93\% (98:2, E:Z).

Scheme 2. Synthesis of key intermediate $\mathbf{1 0 .}$

Accordingly, the starting material $(E)$-allylic alcohol 11 was synthesized according to the reported procedure from D-mannitol. ${ }^{9}$ Thus synthesized $E$-allyl alcohol 11 was subjected to Sharpless catalytic asymmetric epoxidation ${ }^{10}$ by using diethyl L-tartrate, $\operatorname{Ti}\left(\mathrm{O}^{i} \mathrm{Pr}\right)_{4}$ and cumene 
hydroperoxide to afford epoxy alcohol 9 in $93 \%$ yield with 94\% de, determined by GC-MS analysis (see Experimental part). Our next task was to introduce an azido group at C-2 position of 2,3-epoxy alcohol 9 in a highly regioselective manner. Towards that objective, the highly C-2 regioselective azido epoxide opening of 9 was accomplished by using $\mathrm{NaN}_{3}-\left(\mathrm{CH}_{3} \mathrm{O}\right)_{3} \mathrm{~B}$ system developed by Miyashita et al. ${ }^{11}$ Under Miyashita conditions, in our substance the azide nucleophile selectively attacks at the favorable C-2 position rather than at C-3 which is blocked by the hydrogens of the C-5 methylene group ${ }^{12}$ as well as the cyclohexylidene group, affording the single compound $\mathbf{1 2}$ in $95 \%$ yield.

The hydroxyl groups of the obtained azido-diol compound $\mathbf{1 2}$ were protected as benzyl ethers using benzyl bromide, followed by selective deprotection of cyclohexylidene group with $1 \mathrm{~N} \mathrm{HCl}$ in $\mathrm{CH}_{3} \mathrm{CN}$, afforded the 4-azido-1,2-diol 14 in good yield. The obtained azido-diol compound 14 was subjected to oxidative cleavage with $\mathrm{NaIO}_{4}$ to achieve the corresponding aldehyde. This obtained aldehyde was almost pure and without column purification it was subjected to HWE olefination with triethyl phosphonoacetate under Masamune-Roush conditions ${ }^{13}$ to afford the desired, highly $E$ - selective $\alpha, \beta$-unsaturated ethyl ester 10 in $93 \%$ yield $\left(E: Z, 98: 2\right.$ based on ${ }^{1} \mathrm{H}$ NMR analysis).

With compound 10 in hand, the next step was its selective dihydroxylation (Scheme 3). For our study we required both the dihydroxylated compounds, and towards that objective we investigated the stereoselective dihydroxylation of the $\alpha, \beta$-unsaturated ethyl ester $\mathbf{1 0}$ under various reaction conditions; the results are summarized in Table 1.

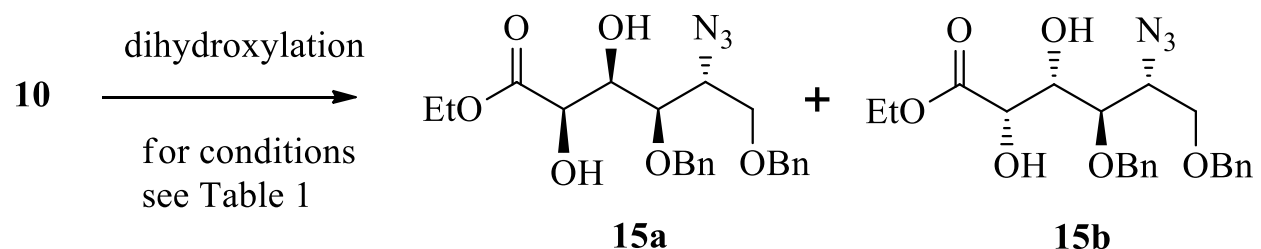

Scheme 3. Dihydroxylation of azido ester 10.

Initially, compound $\mathbf{1 0}$ was treated with the recommended amount of AD-mix $\alpha(1.4 \mathrm{~g} /$ $1 \mathrm{mmol})^{14}$ along with methanesulfonamide at $0{ }^{\circ} \mathrm{C}$ (entry 1). But we observed that the reaction was very slow and even not completed after 5 days. Furthermore the ratio of the vicinal diols was poor in terms of stereoselectivity. In search of the better conditions, it was found that treatment of compound $\mathbf{1 0}$ under modified $\mathrm{SAD}^{15}$ conditions (entry 2) at $0{ }^{\circ} \mathrm{C}$ for 3 days gave the desired diol 15a in $73 \%$ yield after purification $(d r=15 a: 15 b, 94: 6)$. After successful synthesis of compound 15a, we then treated the $\alpha, \beta$-unsaturated ethyl ester 10 with AD-mix $\beta$ (1.4 g/ $1 \mathrm{mmol}$ ), but we did not get a good yield (entry 3 ). Then we applied the modified SAD conditions on ester $\mathbf{1 0}$ (entry 4 ) and the reaction was completed in 3 days and compound $\mathbf{1 5 b}$ was obtained in good yield with improved diastereoselectivity $(\mathrm{dr}=15 \mathrm{a}: 15 \mathrm{~b}, 3: 97)$. However, better results were obtained under Upjohn conditions, on treatment of the compound $\mathbf{1 0}$ with 5 mol \% of $\mathrm{OsO}_{4}$ and $\mathrm{N}$-methylmorpholine oxide $(\mathrm{NMO})^{16}$ as re-oxidant at $0{ }^{\circ} \mathrm{C}$ (entry 5). The reaction was 
completed within $7 \mathrm{~h}$ and resulted in the formation of diol $\mathbf{1 5 b}$ in $91 \%$ yield with good diastereoselectivity $(\mathrm{dr}=15 \mathrm{a}: 15 \mathrm{~b}, 1: 99)$. It was eventually concluded that the slow rate of reaction using the $\mathrm{AD}$-mix reagent (either $\alpha$ or $\beta$ ) is due to steric congestion about the double bond of the ester owing to the OBn group which hinders the approach of the bulky oxidation catalyst to the double bond and also the electron-withdrawing nature of the ester group. ${ }^{14,17}$ This type of interaction between the catalyst and the bulkiness of the substrate in stereoselective dihydroxylation has been reported earlier. ${ }^{18}$

Table 1. Dihydroxylation of olefinic ester $\mathbf{1 0}$ under various reaction conditions

\begin{tabular}{|c|c|c|c|c|c|}
\hline Entry & Reagents & Solvent $^{\mathrm{b}}$ & Time & $15 a: 15 b^{c}$ & $\begin{array}{l}\text { Yield } \\
(\%)^{d}\end{array}$ \\
\hline 1 & $\begin{array}{l}\text { AD-mix } \alpha(1.4 \mathrm{~g} / 1 \mathrm{mmol}), \\
\mathrm{MeSO}_{2} \mathrm{NH}_{2} \text { (1 equiv.) }\end{array}$ & $t-\mathrm{BuOH}-\mathrm{H}_{2} \mathrm{O}(1: 1)$ & 5 days & $84: 16$ & 40 \\
\hline 2 & $\begin{array}{l}\text { AD-mix } \alpha(1.4 \mathrm{~g} / 1 \mathrm{mmol}), \\
(\mathrm{DHQ})_{2}-\mathrm{PHAL}(1 \mathrm{~mol} \%), \\
\mathrm{MeSO}_{2} \mathrm{NH}_{2}(1 \text { equiv. }), \\
\mathrm{NaHCO}_{3}(3 \text { equiv. }), \\
\mathrm{OsO}_{4}(1 \mathrm{~mol} \%),{ }^{\mathrm{a}}\end{array}$ & $t-\mathrm{BuOH}-\mathrm{H}_{2} \mathrm{O}(1: 1)$ & 3 days & $94: 6$ & 78 \\
\hline 3 & $\begin{array}{l}\mathrm{AD}-\operatorname{mix} \beta(1.4 \mathrm{~g} / 1 \mathrm{mmol}) \\
\mathrm{MeSO}_{2} \mathrm{NH}_{2} \text { (1 equiv.) }\end{array}$ & $t-\mathrm{BuOH}-\mathrm{H}_{2} \mathrm{O}(1: 1)$ & 5 days & 10:90 & 44 \\
\hline 4 & $\begin{array}{l}\mathrm{AD}-\operatorname{mix} \beta(1.4 \mathrm{~g} / 1 \mathrm{mmol}), \\
\mathrm{MeSO}_{2} \mathrm{NH}_{2}(1 \text { equiv. }), \\
\mathrm{NaHCO}_{3}(3 \text { equiv. }), \\
\mathrm{NaHCO}_{3}(3 \text { equiv. }), \\
\mathrm{OsO}_{4}(1 \mathrm{~mol} \%),{ }^{a}\end{array}$ & $t-\mathrm{BuOH}-\mathrm{H}_{2} \mathrm{O}(1: 1)$ & 3 days & 3:97 & 82 \\
\hline 5 & $\begin{array}{l}\mathrm{OsO}_{4}(5 \mathrm{~mol} \%),{ }^{\mathrm{a}} \\
\mathrm{NMO}(3 \text { equiv. })\end{array}$ & Acetone- $\mathrm{H}_{2} \mathrm{O}(9: 1)$ & $7 \mathrm{~h}$ & 1:99 & 92 \\
\hline
\end{tabular}

${ }^{\mathrm{a}} 0.04$ molar solution; ${ }^{\mathrm{b}}$ all the reaction were carried out at $0{ }^{\circ} \mathrm{C} ;{ }^{\mathrm{c}}$ based on integration of the crude ${ }^{1} \mathrm{H}$ NMR spectra; ${ }^{\mathrm{d}}$ combined isolated yields.

After completion of these dihydroxylation experiments on the ester 10, we turned our attention to the synthesis of 1-deoxynojirimcycin (Scheme 4). Towards that, azido dihydroxy ester 15a was converted into corresponding acetonide azido ester 16 using 2,2-dimethoxy propane and acetone in presence of PTSA followed by selective reduction of ester group of the compound 16 by $\mathrm{LiBH}_{4}$, generated in situ, ${ }^{19}$ to afford the corresponding alcohol 17 in $87 \%$ yield. In accord with our strategy, a leaving group is required for the construction of the piperidine ring through reductive amino cyclization at the penultimate stage, then the primary hydroxyl group of compound $\mathbf{1 7}$ was mesylated with $\mathrm{MsCl}$ in presence of triethylamine to afford compound $\mathbf{1 8}$ in $93 \%$ yield. 
The piperidine ring closure was achieved by reductive cleavage of the azido group of compound 18 using Lindlar's catalyst $\left(\mathrm{Pd} / \mathrm{CaCO}_{3}\right)$ under hydrogen, followed by base treatment, in $86 \%$ yield. The final target compound 1-deoxynojirimycin (1) was obtained by global deprotection of the benzyl and acetonide groups of 19 with $\mathrm{Pd} / \mathrm{C}$ under hydrogen atmosphere in $\mathrm{MeOH}$ containing 6N HCl, followed by treatment with ion-exchange resin Dowex 50Wx8, in $75 \%$ yield (Scheme 4 ). The spectroscopic and analytical data of 1-deoxynojirimycin 1 were in agreement with literature values. ${ }^{20}$<smiles>CCOC(=O)[C@H](O)[C@@H](O)[C@@H](C(C)C)[C@H](C)COCc1ccccc1</smiles>

$15 \mathbf{a}$

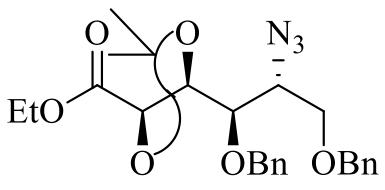

16

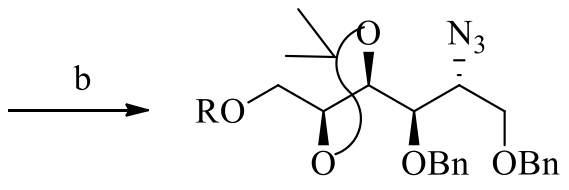

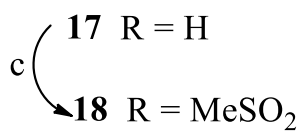<smiles>CC1(C)O[C@H]2CNC(COCc3ccccc3)[C@H](OCc3ccccc3)[C@H]2O1</smiles>

19

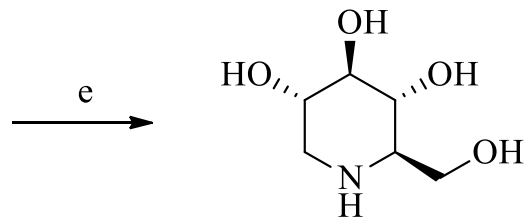

1

Reagents and conditions: (a) 2,2-DMP, acetone, PTSA, rt, overnight, 96\%; (b) $\mathrm{LiCl}, \mathrm{NaBH}_{4}$, THF, EtOH, rt, overnight, 87\%; (c) $\mathrm{MsCl}, \mathrm{Et}_{3} \mathrm{~N}$, DCM, $0{ }^{\circ} \mathrm{C}-\mathrm{rt}, 3 \mathrm{~h}, 93 \%$; (d) $\mathrm{Pd} / \mathrm{CaCO}_{3} / \mathrm{H}_{2}$, $\mathrm{MeOH}, \mathrm{rt}, 6 \mathrm{~h}$, then $\mathrm{K}_{2} \mathrm{CO}_{3}$ reflux, 3 h, 86\%; (e) $\mathrm{Pd} / \mathrm{C}, \mathrm{H}_{2}, \mathrm{MeOH}, 6 \mathrm{~N} \mathrm{HCl}$, rt, 48 h, then Dowex 50wx8 treatment, $75 \%$.

Scheme 4. Synthesis of 1-deoxynojirimycin 1.

After the successful synthesis of 1-deoxynojirimycin 1, we turned our attention to the synthesis of azasugar lactams using the synthesized azido-dihydroxy esters $\mathbf{1 5 a}$ and $\mathbf{1 5} \mathbf{b}$. Under hydrogen atmosphere, using $\mathrm{Pd} / \mathrm{C}$, we have efficiently converted the azido-dihydroxy esters 15a and $\mathbf{1 5 b}$ independently into the corresponding D-glucono- $\delta$-lactam 5 and D-altrono- $\delta$-lactam 6 in one pot, involving debenzylation and reductive lactamization steps, as shown in Scheme 5. The spectroscopic and analytical data of gluconolactam 5 and altronolactam $\mathbf{6}$ were in good agreement with the literature values. ${ }^{20 a, 21}$ 


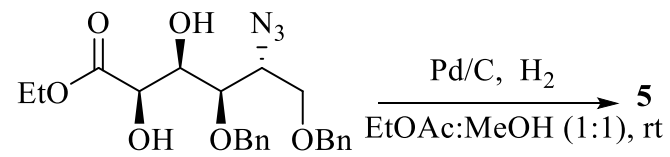

$15 \mathrm{a}$

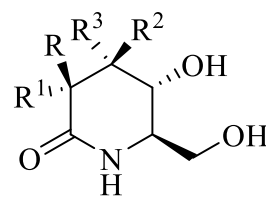

$5 \mathrm{R}, \mathrm{R}^{3}=\mathrm{H}, \mathrm{R}^{1}, \mathrm{R}^{2}=\mathrm{OH}$

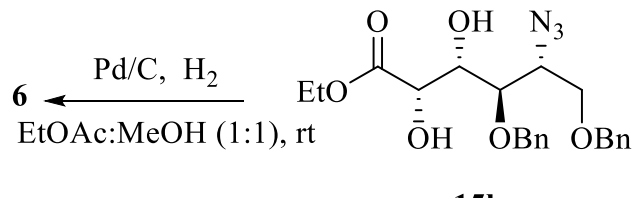

15b

$6 \mathrm{R}, \mathrm{R}^{3}=\mathrm{OH}, \mathrm{R}^{1}, \mathrm{R}^{2}=\mathrm{H}$

Scheme 5. Synthesis of D-glucono- $\delta$-lactam 5 and D-altrono- $\delta$-lactam 6.

\section{Conclusions}

In conclusion, the total synthesis of 1-deoxynojirimycin and the related compounds D-glucono- $\delta$ lactam and D-altrono- $\delta$-lactam has been achieved in a highly stereoselective manner from a common intermediate derived from D-mannitol. A combination of Miyashita C-2 selective endomode azide opening of epoxy alcohol, and Sharpless asymmetric dihydroxylation were employed to generate chiral centers at the desired positions and to obtain the products in good yields. We believe that the synthetic intermediates described in this paper are useful synthons for other natural products and the work is currently under way in this laboratory.

\section{Experimental Section}

General. All reactions were carried out under an inert atmosphere unless mentioned otherwise, and standard syringe-septa techniques were followed. Solvents were freshly dried and purified by conventional methods prior to use. The progress of all the reactions was monitored by TLC, using glass plates precoated with silica gel $60 \mathrm{~F} 254$ to a thickness of $0.5 \mathrm{~mm}$ (Merck). Column chromatography was performed on silica gel (Acme, 60-120 mesh, India); EtOAc and hexane were used as eluents. Optical rotation values were measured either on a Perkin-Elmer P241 polarimeter or Jasco DIP-360 digital polarimeter at $25{ }^{\circ} \mathrm{C}$, and IR spectra were recorded on a Perkin-Elmer FT-IR spectrophotometer. NMR spectra were recorded on a Varian Gemini 200 MHz or Bruker Avance $300 \mathrm{MHz}$ or Varian Unity $400 \mathrm{MHz}$ spectrometer upon their availability, using TMS as an internal standard for ${ }^{1} \mathrm{H}$ NMR and $\mathrm{CDCl}_{3}$ for ${ }^{13} \mathrm{C}$ NMR (chemical shift values in $\delta, J$ in Hz). Mass spectra were recorded on Thermo-Finnigan MAT1020B or Micromass $7070 \mathrm{H}$ spectrometer operating at $70 \mathrm{eV}$ using direct inlet system. All high resolution mass spectra (HRMS) were recorded on QSTAR XL hybrid MS/MS system equipped with an ESI source. GC-MS were recorded on Agilent 6890 series GC-MS system, GC (Agilent Technologies, Palo Alto, CA) equipped with a model 5973N mass selective detector and HP5MS capillary column (5\% phenyl, 95\% PDMS; $30 \mathrm{~m} \times 0.25 \mathrm{~mm}$ i.d $\times 0.25 \mu \mathrm{m}$ film thickness) was used. 
(2R,3R,4R)-2,3-Epoxy-4,5-(cyclohexylidenedioxy)pentan-1-ol (9). To powdered, activated $4 \AA$ molecular sieves $(2.8 \mathrm{~g} \mathrm{35 \%} \mathrm{wt} / \mathrm{wt})$ in dry $\mathrm{CH}_{2} \mathrm{Cl}_{2}(175 \mathrm{~mL})$ under nitrogen were sequentially added titanium tetraisopropoxide $(0.95 \mathrm{~mL}, 3.2 \mathrm{mmol})$ and diethyl $\mathrm{L}-(+)$-tartrate $(0.67 \mathrm{~mL}, 4$ $\mathrm{mmol})$ at $-20{ }^{\circ} \mathrm{C}$, and the mixture was stirred for $30 \mathrm{~min}$. A solution of 11 (8 g, $\left.40.4 \mathrm{mmol}\right)$ in $\mathrm{CH}_{2} \mathrm{Cl}_{2}(50 \mathrm{~mL})$ was added, and the resulting mixture was stirred at $-20{ }^{\circ} \mathrm{C}$ for $30 \mathrm{~min}$. Cumene hydroperoxide $(11.8 \mathrm{~mL}, 80.8 \mathrm{mmol})$ was added dropwise to the reaction mixture, and the resulting solution was stored at $-20{ }^{\circ} \mathrm{C}$ in freezer for $72 \mathrm{~h}$. Aqueous tartaric acid $(10 \%, 40 \mathrm{~mL})$ was added at $-20{ }^{\circ} \mathrm{C}$, and the whole reaction mass was allowed to warm to room temperature, After being stirred for $1 \mathrm{~h}$, the reaction mixture was filtered, and the filtrate was extracted with $\mathrm{CH}_{2} \mathrm{Cl}_{2}(2 \times 75 \mathrm{~mL})$. The combined organic layers were treated with a pre-cooled $\left(0{ }^{\circ} \mathrm{C}\right)$ solution of $25 \mathrm{~mL}$ of $30 \% \mathrm{NaOH}(\mathrm{w} / \mathrm{v})$ in brine at $0{ }^{\circ} \mathrm{C}(25 \mathrm{~mL}$ of $30 \% \mathrm{NaOH}$ solution in brine are prepared by adding $1.25 \mathrm{~g}$ of $\mathrm{NaCl}$ to a solution of $7.5 \mathrm{~g}$ of $\mathrm{NaOH}$ in $22.5 \mathrm{ml}$ of water) and stirred for $20 \mathrm{~min}$. The two layers were separated and the aqueous layer was extracted with $\mathrm{CH}_{2} \mathrm{Cl}_{2}(2 \times 20 \mathrm{~mL})$. The combined organic layers were washed with brine, dried over $\mathrm{Na}_{2} \mathrm{SO}_{4}$, filtered and concentrated. The residue was chromatographed on silica gel with EtOAc-hexane (1:4) to afford pure compound 9 (8 g, 93\%; 94\%de based on GC-MS analysis) as colorless oil; $R_{f}$ $=0.35$ (hexanes-EtOAc, 1:1); $[\alpha]_{\mathrm{D}}{ }^{25}=-23.8$ (c 1.4, MeOH); IR (neat): $\left(v_{\max }, \mathrm{cm}^{-1}\right)$ 3446, 2934, 2859, 1448, 1367, 1162, 1096; ${ }^{1} \mathrm{H}$ NMR $\left(\mathrm{CDCl}_{3}, 300 \mathrm{MHz}\right): \delta_{\mathrm{H}} 4.10-4.03$ (m, 2H, $\left.\mathrm{CH} \mathrm{H}_{2} \mathrm{CH}\right), 3.91$ (br d, $\left.J 13.1 \mathrm{~Hz}, 1 \mathrm{H}, \mathrm{CH}_{\mathrm{a}} \mathrm{H}_{\mathrm{b}} \mathrm{OH}\right), 3.81\left(\mathrm{dd}, J 5.1,7.3 \mathrm{~Hz}, 1 \mathrm{H}, \mathrm{CH}_{2} \mathrm{CH}\right.$ ), 3.64 (br d, $J 13.1 \mathrm{~Hz}, 1 \mathrm{H}$, $\left.\mathrm{CH}_{\mathrm{a}} H_{\mathrm{b}} \mathrm{OH}\right), 3.12(\mathrm{dt}, J 2.1,3.6 \mathrm{~Hz}, 1 \mathrm{H}$, oxirane- $H), 3.04(\mathrm{dd}, J 2.1,3.6 \mathrm{~Hz}, 1 \mathrm{H}$, oxirane- $H), 2.09$ (br s, $1 \mathrm{H}, \mathrm{OH}), 1.59-1.55(\mathrm{~m}, 8 \mathrm{H}, \mathrm{Cy}-H), 1.39$ (br s, $2 \mathrm{H}, \mathrm{Cy}-H) ;{ }^{13} \mathrm{C} \mathrm{NMR}\left(\mathrm{CDCl}_{3}, 50 \mathrm{MHz}\right): \delta_{\mathrm{C}}$

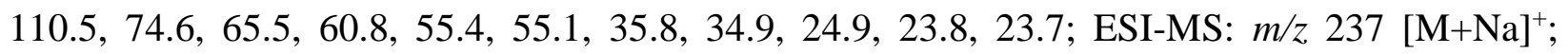
HRMS (ESI): $m / z$ [M+Na] ${ }^{+}$calcd for $\mathrm{C}_{11} \mathrm{H}_{18} \mathrm{O}_{4} \mathrm{Na}$ : 237.1102, found: 237.1088.

GC-MS data: The inlet and GC-MS interface temperatures were kept at $280{ }^{\circ} \mathrm{C}$, Helium was used as the carrier gas at flow rate of $1 \mathrm{~mL} / \mathrm{min}$, and the sample was injected in split mode 1:10 ratio. Oven program was $80{ }^{\circ} \mathrm{C}$ for $2 \mathrm{~min}$.; raised temperature $10{ }^{\circ} \mathrm{C} / \mathrm{min}$ to $280{ }^{\circ} \mathrm{C}$; hold $5 \mathrm{~min}$. The major peak was found at the retention time of $14.07 \mathrm{~min}$. with mass $\mathrm{m} / \mathrm{z} 214[\mathrm{M}]^{+}$and the minor peak was found at $13.75 \mathrm{~min}$. with mass $\mathrm{m} / \mathrm{z} 214[\mathrm{M}]^{+}$.

(2R,3R,4R)-2-Azido-4,5-(cyclohexylidenedioxy)pentane-1,3-diol (12). A mixture of epoxy alcohol 9 (7.5 g, $35 \mathrm{mmol}), \mathrm{B}(\mathrm{OMe})_{3}(7.9 \mathrm{~mL}, 70 \mathrm{mmol})$, and $\mathrm{NaN}_{3}(4.55 \mathrm{~g}, 70 \mathrm{mmol})$ in DMF $(50 \mathrm{~mL})$ under nitrogen atmosphere were stirred at $50{ }^{\circ} \mathrm{C}$ for $6 \mathrm{~h}$. After cooling to $0{ }^{\circ} \mathrm{C}$, a saturated aqueous solution of $\mathrm{NaHCO}_{3}(50 \mathrm{~mL})$ was added, and the mixture was stirred for 30 min at the same temperature. The mixture was separated, and the aqueous layer was extracted with diethyl ether $(3 \times 70 \mathrm{~mL})$. The combined organic layers were successively washed with water $(30 \mathrm{~mL})$, saturated aqueous $\mathrm{NaHCO}_{3}$ solution $(40 \mathrm{~mL})$, brine $(50 \mathrm{~mL})$, and dried over $\mathrm{Na}_{2} \mathrm{SO}_{4}$. Concentration under reduced pressure gave an oily residue, that was dissolved in $\mathrm{CH}_{3} \mathrm{CN}(60 \mathrm{~mL})$ and treated with sodium periodate $(3.75 \mathrm{~g}, 17.5 \mathrm{mmol})$ dissolved in $40 \mathrm{~mL}$ water at room temperature for $30 \mathrm{~min}$ and filtered. The filtrate was mixed with water $(10 \mathrm{~mL})$ and extracted with ethyl acetate $(3 \times 50 \mathrm{~mL})$. The combined organic layers were washed with 
water $(20 \mathrm{~mL})$, brine $(30 \mathrm{~mL})$ and dried over $\mathrm{Na}_{2} \mathrm{SO}_{4}$, filtered and concentrated. The residue was chromatographed on silica gel with EtOAc-hexane (1:4) to give pure 1,3-diol 12 (8.55 g, 95\%) as colorless oil; $R_{f}=0.4$ (hexanes-EtOAc, $\left.1: 1\right) ;[\alpha]_{\mathrm{D}}^{25}=-41.6$ (c 1, MeOH); IR (neat): $\left(v_{\max }, \mathrm{cm}^{-1}\right)$ 3421, 2636, 2860, 2100, 1448, 1276, 1099; ${ }^{1} \mathrm{H} \mathrm{NMR}\left(\mathrm{CDCl}_{3}, 300 \mathrm{MHz}\right): \delta_{\mathrm{H}} 4.34$ (td, J 3.3, 6.7 $\left.\mathrm{Hz}, 1 \mathrm{H}, \mathrm{CH}_{2} \mathrm{CH}\right), 4.13\left(\mathrm{dd}, J 6.7,14.4 \mathrm{~Hz}, 1 \mathrm{H}, \mathrm{CH}_{\mathrm{a}} \mathrm{H}_{\mathrm{b}} \mathrm{CH}\right), 4.02$ (dd, J 3.3, $11.8 \mathrm{~Hz}, 1 \mathrm{H}$, $\mathrm{CH}_{\mathrm{a}} \mathrm{H}_{\mathrm{b}} \mathrm{CH}$ ), 3.92 (dd, J 6.7, 8.3 Hz, 2H, $\left.\mathrm{CH}_{2} \mathrm{OH}\right), 3.56-3.48\left(\mathrm{~m}, 2 \mathrm{H}, \mathrm{CHOH}, \mathrm{CHN}_{3}\right), 2.56$ (br d, $J 6.7 \mathrm{~Hz}, 1 \mathrm{H}, \mathrm{OH}), 2.43$ (br s, $1 \mathrm{H}, \mathrm{OH}), 1.64-1.57$ (m, 8H, Cy- $H$ ), $1.44-1.40(\mathrm{~m}, 2 \mathrm{H}, \mathrm{Cy}-H) ;{ }^{13} \mathrm{C}$ NMR $\left(\mathrm{CDCl}_{3}, 50 \mathrm{MHz}\right): \delta_{\mathrm{C}} 110.2,74.8,70.7,65.6,64.5,62.6,35.8,34.3,24.9,23.9,23.6$; ESIMS: $m / z 280[\mathrm{M}+\mathrm{Na}]^{+}$; HRMS (ESI): $\mathrm{m} / z[\mathrm{M}+\mathrm{Na}]^{+}$calcd for $\mathrm{C}_{11} \mathrm{H}_{19} \mathrm{~N}_{3} \mathrm{O}_{4} \mathrm{Na}$ : 280.1273, found: 280.1267.

(2R,3R,4R)-2-Azido-4,5-(cyclohexylidenedioxy)-1,3-(bisbenzyloxy)pentane (13). To a well stirred solution of $\mathrm{NaH}(60 \%$ dispersion in mineral oil, $3.73 \mathrm{~g}, 93 \mathrm{mmol})$ in dry THF (100 mL) under nitrogen was added azido diol $12(8 \mathrm{~g}, 31 \mathrm{mmol})$ dissolved in THF (40 mL) via syringe very slowly at $0{ }^{\circ} \mathrm{C}$ and allowed to stir at same temperature for $20 \mathrm{~min}$. Then tetrabutylammonium iodide $(100 \mathrm{mg})$ followed by benzyl bromide $(9.26 \mathrm{~mL}, 77 \mathrm{mmol})$ were added and allowed to stir at room temperature until completed the reaction $(16 \mathrm{~h})$. The reaction mixture was quenched by addition of water until clear solution results. THF was removed under reduced pressure, the residue was diluted with water $(20 \mathrm{~mL})$ and extracted with $\mathrm{Et}_{2} \mathrm{O}(3 \times 70$ $\mathrm{mL}$ ). The combined organic layers were dried over $\mathrm{Na}_{2} \mathrm{SO}_{4}$, filtered and concentrated. The residue was chromatographed on silica gel with hexane (100\%) followed by EtOAc-hexane (1: 19) to give pure compound $13(12.8 \mathrm{~g}, 94 \%)$ as colorless oil; $R_{f}=0.6$ (hexanes-EtOAc, 4:1); $[\alpha]_{\mathrm{D}}{ }^{25}=-8.6$ (c 1.4, MeOH); IR (neat): $\left(v_{\max }, \mathrm{cm}^{-1}\right) 2935,2860,2097,1451,1274,1102 ;{ }^{1} \mathrm{H}$ NMR $\left(\mathrm{CDCl}_{3}, 300 \mathrm{MHz}\right): \delta_{\mathrm{H}} 7.29-7.23(\mathrm{~m}, 10 \mathrm{H}, \mathrm{Ar}-H), 4.75(\mathrm{~d}, J 11.3 \mathrm{~Hz}, 1 \mathrm{H}$, benzylic $\left.\mathrm{CH}_{\mathrm{a}} \mathrm{H}_{\mathrm{b}}\right), 4.59\left(\mathrm{~d}, J 11.3 \mathrm{~Hz}, 1 \mathrm{H}, \mathrm{CH}_{\mathrm{a}} H_{\mathrm{b}}\right), 4.52\left(\mathrm{~s}, 2 \mathrm{H}\right.$, benzylic $\left.\mathrm{CH}_{2}\right), 4.24(\mathrm{dd}, J 7.5,11.3 \mathrm{~Hz}$, $\left.1 \mathrm{H}, \mathrm{CH}_{\mathrm{a}} \mathrm{H}_{\mathrm{b}} \mathrm{CH}\right), 3.98\left(\mathrm{dd}, J\right.$ 6.0, 7.5 Hz, 1H, $\left.\mathrm{CH}_{2} \mathrm{CH}\right), 3.80$ (dd, J 2.2, 9.8 Hz, 1H, $\mathrm{CH}_{\mathrm{a}} H_{\mathrm{b}} \mathrm{CH}$ ), 3.70-3.64 (m, 2H, CH $\mathrm{CH}_{2} \mathrm{OBn}$ ), 3.54-3.48 (m, 2H, CHOBn, $\mathrm{CHN}$ ), 1.59-1.56 (m, 8H, Cy-H), 1.38 (br s, $2 \mathrm{H}, \mathrm{Cy}-H) ;{ }^{13} \mathrm{C} \mathrm{NMR}\left(\mathrm{CDCl}_{3}, 50 \mathrm{MHz}\right)$ : $\delta_{\mathrm{C}} 137.8,137.5,128.4,128.3,127.9,127.8$, 127.7, 127.6, 109.7, 78.7, 76.7, 74.5, 73.3, 69.1, 65.6, 62.1, 36.0, 35.0, 25.1, 24.0, 23.8; ESI-MS: $\mathrm{m} / \mathrm{z}, 460[\mathrm{M}+\mathrm{Na}]^{+}$; HRMS (ESI): $\mathrm{m} / z,[\mathrm{M}+\mathrm{Na}]^{+}$calcd for $\mathrm{C}_{25} \mathrm{H}_{31} \mathrm{~N}_{3} \mathrm{O}_{4} \mathrm{Na}$ : 460.2212, found: 460.2204 .

(2R,3R,4R)-4-Azido-3,5-bis(benzyloxy)pentane-1,2-diol (14). To a cooled $\left(0{ }^{\circ} \mathrm{C}\right)$ solution of 13 $(8.74 \mathrm{~g}, 20 \mathrm{mmol})$ in acetonitrile $(100 \mathrm{~mL})$ was added $1 \mathrm{~N} \mathrm{HCl}(100 \mathrm{~mL})$ and allowed to stir at room temperature until starting material disappeared on TLC $(4 \mathrm{~h})$. Then reaction was neutralized with solid sodium bicarbonate at room temperature. The solvent was removed under vacuum, then it was diluted with ethyl acetate $(75 \mathrm{~mL})$ and after separation of the layers, the aqueous layer was further extracted with ethyl acetate $(3 \times 35 \mathrm{~mL})$. The combined organic layers were washed with brine and dried over $\mathrm{Na}_{2} \mathrm{SO}_{4}$, filtered and concentrated. The residue was chromatographed on silica gel with EtOAc-hexane (1:4) to give pure compound 14 (6.785 g, 95\%) as white color solid; $\mathrm{mp} 88-90{ }^{\circ} \mathrm{C} ; R_{f}=0.2$ (hexanes-EtOAc, $1: 1$ ); $[\alpha]_{\mathrm{D}}{ }^{25}=-8.82$ (c 1 , $\mathrm{MeOH})$; IR (KBr): $\left(v_{\max }, \mathrm{cm}^{-1}\right) 3325,2923,2135,2100,1451,1317,1064 ;{ }^{1} \mathrm{H} \mathrm{NMR}\left(\mathrm{CDCl}_{3}, 400\right.$ 
MHz): $\delta_{\mathrm{H}} 7.36-7.24(\mathrm{~m}, 10 \mathrm{H}, \mathrm{Ar}-H), 4.68\left(\mathrm{~d}, J 10.8 \mathrm{~Hz}, 1 \mathrm{H}\right.$, benzylic $\left.\mathrm{CH}_{\mathrm{a}} \mathrm{H}_{\mathrm{b}}\right), 4.59(\mathrm{~d}, J 10.8$ $\mathrm{Hz}, 1 \mathrm{H}$, benzylic $\mathrm{CH}_{\mathrm{a}} \mathrm{H}_{\mathrm{b}}$ ), 4.56 (s, 2H, benzylic $\mathrm{CH}_{2}$ ), 3.90 (dt, $J$ 4.4, 6.6, 1H, CHOH), 3.81 (dd, $J$ 4.4, $\left.10.2 \mathrm{~Hz}, 1 \mathrm{H}, \mathrm{CH}_{a} \mathrm{H}_{b} \mathrm{OH}\right), 3.75$ (dd, J 2.9, $\left.10.2 \mathrm{~Hz}, 1 \mathrm{H}, \mathrm{CH}_{a} H_{b} \mathrm{OH}\right), 3.70-3.64(\mathrm{~m}, 3 \mathrm{H}$, $\mathrm{CH}_{2} \mathrm{OBn}, \mathrm{CHN}$ ), 3.64 (dd, J 4.4, $6.6 \mathrm{~Hz}, 1 \mathrm{H}, \mathrm{CHOBn}$ ), 2.83 (br s, $1 \mathrm{H}, \mathrm{OH}$ ), 1.99 (br s, $1 \mathrm{H}, \mathrm{OH}$ ); ${ }^{13} \mathrm{C} \mathrm{NMR}\left(\mathrm{CDCl}_{3}, 75 \mathrm{MHz}\right): \delta_{\mathrm{C}} 137.4,137.1,128.5,128.4,128.2,128.1,127.9,127.7,77.4$, 74.4, 73.5, 71.2, 69.2, 63.9, 61.6; ESI-MS: $m / z, 380[\mathrm{M}+\mathrm{Na}]^{+}$; HRMS (ESI): $\mathrm{m} / z[\mathrm{M}+\mathrm{Na}]^{+}$calcd for $\mathrm{C}_{19} \mathrm{H}_{23} \mathrm{~N}_{3} \mathrm{O}_{4} \mathrm{Na}$ : 380.1586 , found: 380.1597 .

Ethyl $(4 S, 5 R, 2 E)-5$-azido-4,6-bis(benzyloxy)hex-2-enoate (10). To a stirred solution of 14 $(3.57 \mathrm{~g}, 10 \mathrm{mmol})$ in $48 \mathrm{~mL}$ of acetonitrile at room temperature was added $\mathrm{NaIO}_{4}(4.27 \mathrm{~g}, 20$ $\mathrm{mmol}$ ) dissolved in $32 \mathrm{~mL}$ water over a period of $10 \mathrm{~min}$. The mixture was stirred about $30 \mathrm{~min}$, filtered through pad of celite and repeatedly washed with ethyl acetate. The filtrate was mixed with water $(20 \mathrm{~mL})$ and extracted with ethyl acetate $(3 \times 50 \mathrm{~mL})$. The combined organic layers were washed with water $(20 \mathrm{~mL})$, brine $(40 \mathrm{~mL})$ and dried over $\mathrm{Na}_{2} \mathrm{SO}_{4}$. Solvent removal under reduced pressure afforded the corresponding aldehyde in almost quantitative yield. This was sufficiently pure and hence used as such for the next step. $R_{f}=0.5$ (hexanes-EtOAc, $\left.3: 1\right) ;[\alpha]_{\mathrm{D}}{ }^{25}$ $=+16.0\left(c 1, \mathrm{CHCl}_{3}\right) ;{ }^{1} \mathrm{H} \mathrm{NMR}\left(\mathrm{CDCl}_{3}, 300 \mathrm{MHz}\right): \delta_{\mathrm{H}} 9.56(\mathrm{~d}, J 1.5 \mathrm{~Hz}, 1 \mathrm{H}, \mathrm{CHO}), 7.33-7.23$ $(\mathrm{m}, 10 \mathrm{H}, \operatorname{Ar}-H), 4.73\left(\mathrm{~d}, J 11.3 \mathrm{~Hz}, 1 \mathrm{H}\right.$, benzylic $\left.\mathrm{CH}_{\mathrm{a}} \mathrm{H}_{\mathrm{b}}\right), 4.65(\mathrm{~d}, J 11.3 \mathrm{~Hz}, 1 \mathrm{H}$, benzylic $\mathrm{CH}_{\mathrm{a}} \mathrm{H}_{\mathrm{b}}$ ), 4.49 (s, 2H, benzylic $\mathrm{CH}_{2}$ ), 3.92 (dd, J 1.5, 3.7 Hz, 1H, CHOBn), 3.87 (dt, J 3.7, 6.0 Hz, $1 \mathrm{H}, \mathrm{C} H \mathrm{~N}_{3}$ ), 3.71 (dd, J 6.7, 9.8 Hz, $1 \mathrm{H}, \mathrm{CH}_{a} \mathrm{H}_{\mathrm{b}} \mathrm{OBn}$ ), 3.63 (dd, J 6.0, 9.8 Hz, 1H, $\mathrm{CH}_{\mathrm{a}} H_{\mathrm{b}} \mathrm{OBn}$ ). ${ }^{13} \mathrm{C} \mathrm{NMR}\left(\mathrm{CDCl}_{3}, 75 \mathrm{MHz}\right): \delta_{\mathrm{C}} 200.8,137.2,136.5,128.5,128.4,128.3,128.1,127.8,127.6$, 82.5, 73.4, 67.6, 61.4; ESI-MS: $m / z 348[\mathrm{M}+\mathrm{Na}]^{+}$.

To a well stirred solution of anhydrous $\mathrm{LiCl}(492 \mathrm{mg}, 11.6 \mathrm{mmol})$ in dry acetonitrile $(35 \mathrm{~mL})$ under nitrogen were sequentially added triethyl phosphonoacetate $(2.3 \mathrm{~mL}, 11.6 \mathrm{mmol}), \mathrm{N}, \mathrm{N}-$ diisopropylethylamine $(2 \mathrm{~mL}, 11.6 \mathrm{mmol})$ and above freshly prepared aldehyde $(3.15 \mathrm{~g}, 9.7$ $\mathrm{mmol})$ dissolved in acetonitrile $(25 \mathrm{~mL})$ at room temperature and the mixture was stirred at $\mathrm{rt}$ for $16 \mathrm{~h}$. The reaction mixture was diluted with water $(40 \mathrm{~mL})$, extracted with EtOAc $(2 \times 75 \mathrm{~mL})$ and the combined organic layers were washed with brine $(40 \mathrm{~mL})$, dried over $\mathrm{Na}_{2} \mathrm{SO}_{4}$, filtered and concentrated gave an oily residue which was chromatographed on silica gel with EtOAchexane (1:49) gave highly predominant $E$-isomer $\mathbf{1 0}$ (inseparable $E$ and $Z$ isomers in 98:2 ratio, based on crude ${ }^{1} \mathrm{H}-\mathrm{NMR} ; 3.66 \mathrm{~g}, 93 \%$ ) as colorless oil; $R_{f}=0.55$ (hexanes-EtOAc, $3: 1$ ); $[\alpha]_{\mathrm{D}}{ }^{25}=$ +29.8 (c, 1.0, $\left.\mathrm{CHCl}_{3}\right)$; IR (neat): $\left(v_{\max }, \mathrm{cm}^{-1}\right)$ 2866, 2100, 1720, 1454, 1271, 1175, 1097; ${ }^{1} \mathrm{H}$ NMR $\left(\mathrm{CDCl}_{3}, 300 \mathrm{MHz}\right): \delta_{\mathrm{H}} 7.32-723(\mathrm{~m}, 10 \mathrm{H}, \mathrm{Ar}-H), 6.85(\mathrm{dd}, J 6.7,15.8 \mathrm{~Hz}, 1 \mathrm{H},=\mathrm{CH}), 6.05$ $(\mathrm{d}, J 15.8 \mathrm{~Hz}, 1 \mathrm{H},=\mathrm{CH}), 4.62\left(\mathrm{~d}, J=12.0 \mathrm{~Hz}, 1 \mathrm{H}\right.$, benzylic $\left.\mathrm{CH}_{\mathrm{a}} \mathrm{H}_{\mathrm{b}}\right), 4.49\left(\mathrm{~s}, 2 \mathrm{H}\right.$, benzylic $\left.\mathrm{CH}_{2}\right)$, $4.40\left(\mathrm{~d}, J 12.0 \mathrm{~Hz}, 1 \mathrm{H}\right.$, benzylic $\left.\mathrm{CH}_{\mathrm{a}} H_{\mathrm{b}}\right), 4.25\left(\mathrm{q}, J 7.5 \mathrm{~Hz}, 2 \mathrm{H}, \mathrm{CH}_{2} \mathrm{CH}_{3}\right), 4.16(\mathrm{t}, J 5.2 \mathrm{~Hz}, 1 \mathrm{H}$, CHOBn), 3.68 (dd, J 5.8, $11.7 \mathrm{~Hz}, 1 \mathrm{H}, \mathrm{CHN}_{3}$ ), 3.60 (d, J 5.2 Hz, 2H, CH $\mathrm{H}_{2} \mathrm{OBn}$ ), 1.34 (t, J 7.5 $\left.\mathrm{Hz}, 3 \mathrm{H}, \mathrm{CH}_{3}\right) ;{ }^{13} \mathrm{C} \mathrm{NMR}\left(\mathrm{CDCl}_{3}, 50 \mathrm{MHz}\right): \delta_{\mathrm{C}} 165.5,143.4,137.4,137.2,128.4,128.3,127.9$, 127.8, 127.7, 127.6, 124.9, 77.5, 73.4, 71.5, 68.8, 63.7, 60.6, 14.2; ESI-MS: $m / z$. 418 [M+Na] ${ }^{+}$; HRMS (ESI): $m / z$ [M+Na] ${ }^{+}$calcd for $\mathrm{C}_{22} \mathrm{H}_{25} \mathrm{~N}_{3} \mathrm{O}_{4} \mathrm{Na}$ : 418.1742, found: 418.1745 .

Ethyl (2R,3R,4R,5R)-5-azido-4,6-bis(benzyloxy)-2,3-dihydroxyhexanoate (15a). To a stirred solution of AD-mix $\alpha(5.6 \mathrm{~g}, 1.4 \mathrm{~g} / 1 \mathrm{mmol})$ in $\mathrm{t}-\mathrm{BuOH}$ and $\mathrm{H}_{2} \mathrm{O}\left(10 \mathrm{~mL} t\right.$-BuOH $\left.+20 \mathrm{~mL} \mathrm{H} \mathrm{H}_{2} \mathrm{O}\right)$ 
at room temperature were added 0.04 molar toluene solution of $\mathrm{OsO}_{4}(1 \mathrm{~mL}, 0.04 \mathrm{mmol}, 1$ mol\%), (DHQ) 2 PHAL (125 mg, $0.16 \mathrm{mmol}), \mathrm{NaHCO}_{3}(1 \mathrm{~g}, 12 \mathrm{mmol})$ and $\mathrm{MeSO}_{2} \mathrm{NH}_{2}(380 \mathrm{mg}$, $4 \mathrm{mmol}$ ) sequentially. After $20 \mathrm{~min}$ the clear solution was cooled to $0{ }^{\circ} \mathrm{C}$ and was added compound $10(1.58 \mathrm{~g}, 4 \mathrm{mmol}))$ dissolved in $t$-BuOH $(10 \mathrm{~mL})$ at once and allowed to stir at $0{ }^{\circ} \mathrm{C}$ until completed the reaction $(72 \mathrm{~h})$, then the reaction mixture was quenched with solid $\mathrm{Na}_{2} \mathrm{SO}_{3}$ $(3.5 \mathrm{~g})$ at $0{ }^{\circ} \mathrm{C}$ and stirred for $30 \mathrm{~min}$ then warmed to room temperature. Ethyl acetate $(50 \mathrm{~mL})$ was added to the reaction mixture and separated the aqueous layer from organic layer. The aqueous layer further extracted with ethyl acetate $(2 \times 40 \mathrm{~mL})$, the combined organic layers were dried over $\mathrm{Na}_{2} \mathrm{SO}_{4}$, filtered and concentrated. The crude residue was chromatographed on silica gel with EtOAc-hexane (1:9) to give pure compound 15a $(1.26 \mathrm{~g}, 73 \%)$ as pale yellow solid; $\mathrm{mp}$ $43-45{ }^{\circ} \mathrm{C} ; R_{f}=0.33$ (hexanes-EtOAc, 7:3); $[\alpha]_{\mathrm{D}}{ }^{25}=-21.7\left(c 0.47, \mathrm{CHCl}_{3}\right)$; IR (neat): $\left(v_{\max }, \mathrm{cm}^{-1}\right)$ 3545, 3358, 2866, 2108, 1730, 1202, 1107, 1055; ${ }^{1} \mathrm{H}$ NMR $\left(\mathrm{CDCl}_{3}, 300 \mathrm{MHz}\right): \delta_{\mathrm{H}} 7.34-7.26$ $(\mathrm{m}, 10 \mathrm{H}, \operatorname{Ar}-H), 4.74\left(\mathrm{~d}, J 10.4 \mathrm{~Hz}, 1 \mathrm{H}\right.$, benzylic $\left.\mathrm{CH}_{\mathrm{a}} \mathrm{H}_{\mathrm{b}}\right), 4.61(\mathrm{~d}, J 10.4 \mathrm{~Hz}, 1 \mathrm{H}$, benzylic $\left.\mathrm{CH}_{\mathrm{a}} H_{\mathrm{b}}\right), 4.58$ (dd, $J 12.4,14.5 \mathrm{~Hz}, 2 \mathrm{H}$, benzylic $\left.\mathrm{CH}_{2}\right), 4.41$ (br d, J 3.1 Hz, 1H, CHOH), 4.28 (m, $2 \mathrm{H}, \mathrm{CH}_{2} \mathrm{CH}_{3}$ ), 4.05 (dd, J 3.1, $\left.5.2 \mathrm{~Hz}, 1 \mathrm{H}, \mathrm{CHOH}\right), 4.01$ (dd, J 6.2, $14.5 \mathrm{~Hz}, 1 \mathrm{H}, \mathrm{CHOBn}$ ), 3.81 (dd, J 5.2, $10.4 \mathrm{~Hz}, 1 \mathrm{H}, \mathrm{CH}_{\mathrm{a}} \mathrm{H}_{\mathrm{b}} \mathrm{OBn}$ ), 3.73-3.69 (m, 2H, $\mathrm{CH}_{\mathrm{a}} \mathrm{H}_{\mathrm{b}} \mathrm{OBn}, \mathrm{CHN}_{3}$ ), 3.07 (br d, J 4.1 Hz, $1 \mathrm{H}, \mathrm{OH}), 2.55(\mathrm{br} d, J 8.3 \mathrm{~Hz}, 1 \mathrm{H}, \mathrm{OH}), 1.30\left(\mathrm{t}, J 7.2 \mathrm{~Hz}, 3 \mathrm{H}, \mathrm{CH}_{3}\right) ;{ }^{13} \mathrm{C} \mathrm{NMR}_{\left(\mathrm{CDCl}_{3}, 75\right.}$ $\mathrm{MHz}): \delta_{\mathrm{C}} 172.9,137.4,137.3,128.4,128.0,127.8,127.7,77.6,74.2,73.4,71.4,71.2,69.2,62.2$, 62.0, 14.0; ESI-MS: $m / z 452[\mathrm{M}+\mathrm{Na}]^{+}$; HRMS (ESI): $\mathrm{m} / z[\mathrm{M}+\mathrm{Na}]^{+}$calcd for $\mathrm{C}_{22} \mathrm{H}_{27} \mathrm{~N}_{3} \mathrm{O}_{6} \mathrm{Na}$ : 452.1797, found: 452.1813 .

Ethyl $\quad(2 S, 3 S, 4 R, 5 R)-5$-azido-4,6-bis(benzyloxy)-2,3-dihydroxyhexanoate $\quad(15 b) . \quad$ The dihydroxy compound 15b was synthesized using AD-mix $\beta$ (1.4 g/1 mmol) from 10 without employing a specific ligand (Table 1, entry 4) according to the procedure described for the synthesis of $\mathbf{1 5 a}$ from $\mathbf{1 0}$. The same dihydroxy compound $\mathbf{1 5 b}$ was synthesized using a catalytic amount of $\mathrm{OsO}_{4}$ as described below.

To a cooled $\left(0{ }^{\circ} \mathrm{C}\right)$ solution of ester compound $\mathbf{1 0}(1.58 \mathrm{~g}, 4 \mathrm{mmol})$ and NMO (1.62 g, $\left.12 \mathrm{mmol}\right)$ in acetone: $\mathrm{H}_{2} \mathrm{O}(20 \mathrm{~mL}, 9: 1)$ was added $0.04 \mathrm{M}$ toluene solution of $\mathrm{OsO}_{4}(5 \mathrm{~mL}, 5 \mathrm{~mol} \%)$. The solution was stirred until the reaction was completed at $0{ }^{\circ} \mathrm{C}$ (TLC analysis ca. $7 \mathrm{~h}$ ). The reaction was quenched by saturated aqueous sodium sulfite $(8 \mathrm{~mL})$ and the organic solvent was removed in vacuo. $\mathrm{CH}_{2} \mathrm{Cl}_{2}(40 \mathrm{~mL})$ was added, separated the layers and the aqueous layers was extracted with $\mathrm{CH}_{2} \mathrm{Cl}_{2}(2 \times 20 \mathrm{~mL})$ and the combined organic layers were washed with brine $(30 \mathrm{~mL})$, dried over $\mathrm{Na}_{2} \mathrm{SO}_{4}$, and concentrated. The crude residue was chromatographed on silica gel using EtOAc-hexane (1:9) as eluent to give pure compound $\mathbf{1 5 b}(1.55 \mathrm{~g}, 91 \%)$ as colorless oil; $R_{f}=0.3$ (hexanes-EtOAc, 7:3); $[\alpha]_{\mathrm{D}}{ }^{25}=-14.8\left(c 0.5, \mathrm{CHCl}_{3}\right.$, compound synthesized using AD-mix- $\beta$ ); $[\alpha]_{\mathrm{D}}^{25}=-15.2\left(\mathrm{c} 0.5, \mathrm{CHCl}_{3}\right.$, compound synthesized using $\left.\mathrm{OsO}_{4}\right)$; IR (neat): $\left(v_{\max }, \mathrm{cm}^{-1}\right) 3414$, 2937, 2861, 2103, 1448, 1277, 1099; ${ }^{1} \mathrm{H}$ NMR $\left(\mathrm{CDCl}_{3}, 300 \mathrm{MHz}\right): \delta_{\mathrm{H}} 7.34-7.29$ (m, 10H, Ar-H), $4.76\left(\mathrm{~d}, J 10.9 \mathrm{~Hz}, 1 \mathrm{H}\right.$, benzylic $\left.\mathrm{CH}_{\mathrm{a}} \mathrm{H}_{\mathrm{b}}\right), 4.63\left(\mathrm{~d}, J 10.9 \mathrm{~Hz}, 1 \mathrm{H}\right.$, benzylic $\left.\mathrm{CH}_{\mathrm{a}} H_{\mathrm{b}}\right), 4.56(\mathrm{~s}, 2 \mathrm{H}$, benzylic $\mathrm{CH}_{2}$ ), 4.45 (br d, J 4.1 Hz, 1H, CHOH), 4.30-4.20 (m, 2H, $\mathrm{CH}_{2} \mathrm{CH}_{3}$ ), 4.09-4.02 (m, 2H, $\mathrm{CHOH}, \mathrm{CHOBn}), 3.82-3.70\left(\mathrm{~m}, 3 \mathrm{H}, \mathrm{CH}_{2} \mathrm{OBn}, \mathrm{CHN}\right.$ ), 3.12 (br d, J 5.2 Hz, 1H, OH), 2.65 (br d, $J 8.6 \mathrm{~Hz}, 1 \mathrm{H}, \mathrm{OH}), 1.30(\mathrm{t}, J 7.1 \mathrm{~Hz}, 3 \mathrm{H}, \mathrm{CH}) ;{ }^{13} \mathrm{C} \mathrm{NMR}\left(\mathrm{CDCl}_{3}, 75 \mathrm{MHz}\right): \delta_{\mathrm{C}} 173.5,137.4$, 
137.4, 128.4, 128.0, 127.9, 127.8, 127.7, 78.8, 74.1 73.4, 71.5, 70.3, 69.2, 62.6, 62.2, 14.1; ESIMS: $m / z 452[\mathrm{M}+\mathrm{Na}]^{+}$; HRMS (ESI): $\mathrm{m} / z[\mathrm{M}+\mathrm{Na}]^{+}$calcd for $\mathrm{C}_{22} \mathrm{H}_{27} \mathrm{~N}_{3} \mathrm{O}_{6} \mathrm{Na}$ : 452.1797, found: 452.1808 .

Ethyl $(2 R, 3 S, 4 R, 5 R)-5$-azido-2,3-(isopropylidenedioxy)-4,6-bis(benzyloxy)hexanoate (16). A solution of ester 15a $(2.15 \mathrm{~g}, 5 \mathrm{mmol})$ and PTSA $(11 \mathrm{mg}, 0.5 \mathrm{wt} \%)$ in 2,2-dimethoxypropane (DMP) $(4 \mathrm{~mL})$ and dry acetone $(8 \mathrm{~mL})$ was stirred at room temperature for overnight. $0.5 \mathrm{~mL}$ saturated aqueous $\mathrm{NaHCO}_{3}$ solution were added to the mixture and excess of DMP and acetone was removed under reduced pressure. The residue was treated with water and the mixture was extracted with ethyl acetate $(2 \times 50 \mathrm{~mL})$. The combined organic layer was washed with brine $(30$ $\mathrm{mL}$ ) and dried over $\mathrm{Na}_{2} \mathrm{SO}_{4}$, the solvent was removed in vacuo and the crude product was purified by column chromatography using silica gel and EtOAc-hexane (1:9) as eluent to give pure compound $16(2.25 \mathrm{~g}, 96 \%)$ as a colorless oil; $R_{f}=0.4$ (hexanes-EtOAc, $\left.4: 1\right) ;[\alpha]_{\mathrm{D}}{ }^{25}=-33.6$ (c $\left.0.59, \mathrm{CHCl}_{3}\right)$; IR (neat): $\left(v_{\max }, \mathrm{cm}^{-1}\right)$ 2987, 2930, 2100, 1757, 1375, 1206, 1102; ${ }^{1} \mathrm{H}$ NMR $\left(\mathrm{CDCl}_{3}, 400 \mathrm{MHz}\right): \delta_{\mathrm{H}} 7.31-7.21(\mathrm{~m}, 10 \mathrm{H}, \mathrm{Ar}-H), 4.63\left(\mathrm{~s}, 2 \mathrm{H}\right.$, benzylic $\left.\mathrm{CH}_{2}\right), 4.58(\mathrm{~d}, J 11.7 \mathrm{~Hz}$, $1 \mathrm{H}$, benzylic $\left.\mathrm{CH}_{\mathrm{a}} \mathrm{H}_{\mathrm{b}}\right), 4.54\left(\mathrm{~d}, J 12.6 \mathrm{~Hz}, 1 \mathrm{H}\right.$, benzylic $\left.\mathrm{CH}_{\mathrm{a}} H_{\mathrm{b}}\right), 4.38(\mathrm{~d}, J 7.8 \mathrm{~Hz}, 1 \mathrm{H}, \mathrm{C}(2) H)$, $4.33(\mathrm{dd}, J 2.9,7.8 \mathrm{~Hz}, 1 \mathrm{H}, \mathrm{C}(3) H), 4.23\left(\mathrm{q}, J 6.8 \mathrm{~Hz}, 2 \mathrm{H}, \mathrm{CH}_{2} \mathrm{CH}_{3}\right), 3.83(\mathrm{dd}, J 4.8,11.7 \mathrm{~Hz}$, $1 \mathrm{H}, \mathrm{CH}_{\mathrm{a}} \mathrm{H}_{\mathrm{b}} \mathrm{OBn}$ ), 3.74-3.68 (m, 3H, $\left.\mathrm{CH}_{\mathrm{a}} \mathrm{H}_{\mathrm{b}} \mathrm{OBn}, \mathrm{CHOBn}, \mathrm{CHN} 3\right), 1.42\left(\mathrm{~s}, 6 \mathrm{H}, 2 \times \mathrm{CH}_{3}\right), 1.31$ (t, $\left.J 6.8 \mathrm{~Hz}, 3 \mathrm{H}, \mathrm{CH}_{2} \mathrm{CH}_{3}\right) ;{ }^{13} \mathrm{C} \mathrm{NMR}\left(\mathrm{CDCl}_{3}, 75 \mathrm{MHz}\right): \delta_{\mathrm{C}} 170.4,137.5,137.3,128.4,127.9$, $127.8,127.7,127.6,111.2,79.0,75.9,74.8,74.7,73.3,69.2,61.7,61.5,26.6,25.8,14.1$. ESIMS: $m / z 492(18 \%)[\mathrm{M}+\mathrm{Na}], 487(100 \%)\left(\mathrm{M}+\mathrm{NH}_{3}\right), 442(98 \%)\left(\mathrm{M}+\mathrm{H}_{-} \mathrm{N}_{2}\right) ; \mathrm{HRMS}(\mathrm{ESI}): \mathrm{m} / z$ $[\mathrm{M}+\mathrm{Na}]^{+}$calcd for $\mathrm{C}_{25} \mathrm{H}_{31} \mathrm{~N}_{3} \mathrm{O}_{6} \mathrm{Na}: 492.2110$, found: 492.2107.

(2S,3S,4R,5R)-5-Azido-2,3-isopropylidenedioxy-4,6-bis(benzyloxy)-hexan-1-ol (17). An ice cooled solution of anhydrous $\mathrm{LiCl}(637 \mathrm{mg}, 15 \mathrm{mmol})$ and $\mathrm{NaBH}_{4}(567 \mathrm{mg}, 15 \mathrm{mmol})$ in dry ethanol (15 mL) was stirred for $30 \mathrm{~min}$, to it azido ester 16 (2.35 g, $5 \mathrm{mmol})$ dissolved in dry THF (15 mL) was added over $10 \mathrm{~min}$. The reaction mixture was brought to room temperature and stirred for overnight. The solid precipitate was filtered and washed with EtOAc $(20 \mathrm{~mL})$ and $\mathrm{EtOH}(10 \mathrm{~mL})$. The filtrate was concentrated in vacuo and the residue was dissolved in EtOAc, treated with saturated $\mathrm{NH}_{4} \mathrm{Cl}(50 \mathrm{~mL})$ at $0{ }^{\circ} \mathrm{C}$ and extracted with EtOAc $(3 \times 50 \mathrm{~mL})$. The combined organic layers were washed with brine, dried over $\mathrm{Na}_{2} \mathrm{SO}_{4}$ and the solvent was removed under vacuo. The residue was purified by column chromatography using silica gel and EtOAc-hexane (1:9 followed by $1: 4)$ as eluent to give pure compound $17(1.85 \mathrm{~g},(87 \%)$ as colorless oil; $R_{f}=0.25$ (hexanes-EtOAc, $\left.4: 1\right) ;[\alpha]_{\mathrm{D}}{ }^{25}=-24.2\left(c 0.62, \mathrm{CHCl}_{3}\right)$; IR (neat): ( $v_{\max }$, $\left.\mathrm{cm}^{-1}\right) 3421,2925,2101,1722,1265,1098 ;{ }^{1} \mathrm{H}$ NMR $\left(\mathrm{CDCl}_{3}, 300 \mathrm{MHz}\right): \delta_{\mathrm{H}} 7.33-7.21(\mathrm{~m}, 10 \mathrm{H}$, Ar- $H), 4.64\left(\mathrm{~d}, J 11.5 \mathrm{~Hz}, 1 \mathrm{H}\right.$, benzylic $\left.\mathrm{CH}_{\mathrm{a}} \mathrm{H}_{\mathrm{b}}\right), 4.56\left(\mathrm{~d}, J 11.5 \mathrm{~Hz}, 1 \mathrm{H}\right.$, benzylic $\left.\mathrm{CH}_{\mathrm{a}} H_{\mathrm{b}}\right), 4.55(\mathrm{~s}$, $2 \mathrm{H}$, benzylic $\mathrm{CH}_{2}$ ), 4.05 (dd, $\left.J 2.4,8.3 \mathrm{~Hz}, 1 \mathrm{H}, \mathrm{C}(3) H\right), 3.95(\mathrm{dt}, J 4.3,8.3 \mathrm{~Hz}, 1 \mathrm{H}, \mathrm{C}(2) H), 3.82-$ 3.69 (m, 3H, CH$\left.H_{2} \mathrm{OH}, \mathrm{CHOBn}\right), 3.59-3.53$ (m, 2H, $\mathrm{CH}_{\mathrm{a}} \mathrm{H}_{\mathrm{b}} \mathrm{OBn}, \mathrm{CHN}$ ), 3.43 (dd, J 3.9, $11.8 \mathrm{~Hz}$, $\left.1 \mathrm{H}, \mathrm{CH}_{\mathrm{a}} H_{\mathrm{b}} \mathrm{OBn}\right), 1.76$ (br s, $\left.1 \mathrm{H}, \mathrm{OH}\right), 1.36\left(\mathrm{~s}, 6 \mathrm{H} 2 \times \mathrm{CH}_{3}\right) ;{ }^{13} \mathrm{C} \mathrm{NMR}\left(\mathrm{CDCl}_{3}, 75 \mathrm{MHz}\right): \delta_{\mathrm{C}}$ 137.5, 137.4, 128.4, 128.3, 128.2, 128.0, 127.8, 109.0, 77.6, 76.7, 75.7, 74.3, 73.5, 69.3, 62.1, 61.7, 27.3, 26.9; ESI-MS: $m / z$ 428 [M+H] $]^{+}$; HRMS (ESI): $m / z[\mathrm{M}+\mathrm{Na}]^{+}$calcd for $\mathrm{C}_{23} \mathrm{H}_{29} \mathrm{~N}_{3} \mathrm{O}_{5} \mathrm{Na}$ : 450.2004, found: 450.2002. 
(2S,3S,4R,5R)-5-Azido-4,6-bis(benzyloxy)-2,3-isopropylidenedioxy-1-methanesulfonyloxyhexane (18). To a stirred cooled $\left(0{ }^{\circ} \mathrm{C}\right)$ solution containing alcohol $17(1.71 \mathrm{~g}, 4 \mathrm{mmol})$ and $\mathrm{Et}_{3} \mathrm{~N}$ $(2.3 \mathrm{~mL}, 16 \mathrm{mmol})$ in DCM $(40 \mathrm{~mL})$ was added methanesulfonyl chloride $(\mathrm{MsCl}, 0.92 \mathrm{~mL}, 8$ $\mathrm{mmol}$ ) and the mixture was allowed to warm to room temperature and stirred until the alcohol disappeared on TLC $(3 \mathrm{~h})$. Then the reaction was quenched with water $(5 \mathrm{~mL})$, extracted with DCM $(2 \times 25 \mathrm{~mL})$ and the organic layer was washed with brine, then dried over $\mathrm{Na}_{2} \mathrm{SO}_{4}$, concentrated, and the residue was purified by column chromatography using silica gel and EtOAc-hexanes (1:19) as eluent to give pure compound $18(1.92 \mathrm{~g}, 93 \%)$ as colorless oil; $R_{f}=$ 0.6 (hexanes-EtOAc, 4:1); $[\alpha]_{\mathrm{D}}{ }^{25}=-39.7$ (c 0.39, $\mathrm{CHCl}_{3}$ ); IR (neat): ( $\left.v_{\max }, \mathrm{cm}^{-1}\right)$ 3030, 2936, 2099, 1454, 1358, 1215, 1175; ${ }^{1} \mathrm{H}$ NMR $\left(\mathrm{CDCl}_{3}, 300 \mathrm{MHz}\right)$ : $\delta_{\mathrm{H}} 7.33-7.21(\mathrm{~m}, 10 \mathrm{H}, \mathrm{Ar}-H), 4.64$ $\left(\mathrm{d}, J 11.3 \mathrm{~Hz}, 1 \mathrm{H}\right.$, benzylic $\left.\mathrm{CH}_{\mathrm{a}} \mathrm{H}_{\mathrm{b}}\right), 4.57\left(\mathrm{~d}, J 3.9 \mathrm{~Hz}, 2 \mathrm{H}\right.$, benzylic $\left.\mathrm{CH}_{2}\right), 4.54(\mathrm{~d}, J 11.3 \mathrm{~Hz}, 1 \mathrm{H}$, benzylic $\mathrm{CH}_{\mathrm{a}} H_{\mathrm{b}}$ ), 4.14-4.06 (m, 2H, C(2)H, C(3)H), 4.03-3.97 (m, 2H, CH2OMs), 3.84-3.77 (m, $2 \mathrm{H}, \mathrm{CH}_{2} \mathrm{OBn}$ ), 3.74 (dd, J 4.5, $\left.7.7 \mathrm{~Hz}, 1 \mathrm{H}, \mathrm{CHOBn}\right), 3.59$ (dd, J 2.0, $7.3 \mathrm{~Hz}, 1 \mathrm{H}, \mathrm{CHN}$ ), 2.96 (s, $\left.3 \mathrm{H}, \mathrm{CH}_{3}\right), 1.38\left(\mathrm{~s}, 3 \mathrm{H}, \mathrm{CH}_{3}\right), 1.37\left(\mathrm{~s}, 3 \mathrm{H}, \mathrm{CH}_{3}\right) ;{ }^{13} \mathrm{C} \mathrm{NMR}\left(\mathrm{CDCl}_{3}, 75 \mathrm{MHz}\right): \delta_{\mathrm{C}} 137.4,137.0$, 128.5, 128.4, 128.3, 128.2, 127.8, 110.0, 77.4, 74.9, 74.3, 74.1, 73.4, 69.0, 68.3, 61.8, 37.6, 26.9, 26.7; ESI-MS: $\mathrm{m} / \mathrm{z} 528[\mathrm{M}+\mathrm{Na}]^{+}$; HRMS (ESI): $\mathrm{m} / z \quad[\mathrm{M}+\mathrm{Na}]^{+}$calcd for $\mathrm{C}_{24} \mathrm{H}_{31} \mathrm{~N}_{3} \mathrm{O}_{7} \mathrm{SNa}$ : 528.1780, found: 528.1804 .

(2R,3R,4R,5S)-3-Benzyloxy-2-benzyloxymethyl-4,5-isopropylidenedioxypiperidine (19). A mixture of mesyl compound 18 ( $1 \mathrm{~g}, 2 \mathrm{mmol})$ and Lindlar's catalyst (20\% content, 30\% wt/wt, $300 \mathrm{mg}$ ) in EtOAc $(20 \mathrm{~mL})$ was stirred at room temperature under $\mathrm{H}_{2}$ (balloons) atmosphere for $6 \mathrm{~h}$. Then the reaction mixture was filtered through celite and washed with EtOAc $(5 \mathrm{~mL})$, $\mathrm{K}_{2} \mathrm{CO}_{3}$ (276 $\mathrm{mg}, 2 \mathrm{mmol}$ ) was added to the filtrate, and the mixture was refluxed for $3 \mathrm{~h}$. then it was concentrated in vacuo to remove the solvents. The crude mass was chromatographed through silica gel using EtOAc-hexanes (1:9) as eluent to give pure compound 19 (665 mg, 86\%) as colorless oil; $R_{f}=0.5$ (hexanes-EtOAc, $\left.1: 1\right) ;[\alpha]_{\mathrm{D}}^{25}=+67.4\left(c 0.5, \mathrm{CHCl}_{3}\right)$; IR (neat): $\left(v_{\max }\right.$, $\left.\mathrm{cm}^{-1}\right) 3338,2922,2853,1456,1374,1231,1084,750 ;{ }^{1} \mathrm{H}$ NMR $\left(\mathrm{CDCl}_{3}, 300 \mathrm{MHz}\right): \delta_{\mathrm{H}} 7.31-7.21$ $(\mathrm{m}, 10 \mathrm{H}, \mathrm{Ar}-H), 4.85\left(\mathrm{~d}, J 11.7 \mathrm{~Hz}, 1 \mathrm{H}\right.$, benzylic $\left.\mathrm{CH}_{\mathrm{a}} \mathrm{H}_{\mathrm{b}}\right), 4.53(\mathrm{~d}, J 11.7 \mathrm{~Hz}, 1 \mathrm{H}$, benzylic $\left.\mathrm{CH}_{\mathrm{a}} H_{\mathrm{b}}\right), 4.47\left(\mathrm{~d}, J 11.7 \mathrm{~Hz}, 1 \mathrm{H}\right.$, benzylic $\left.\mathrm{CH}_{\mathrm{a}} \mathrm{H}_{\mathrm{b}}\right), 4.39\left(\mathrm{~d}, J 11.8 \mathrm{~Hz}, 1 \mathrm{H}\right.$, benzylic $\left.\mathrm{CH}_{\mathrm{a}} H_{\mathrm{b}}\right), 3.69-$ $3.61(\mathrm{~m}, 2 \mathrm{H}, \mathrm{C}(3) H, \mathrm{C}(4) H)$, 3.53-3.36 (m, 2H, C(5)H, $\left.\mathrm{CH}_{\mathrm{a}} \mathrm{H}_{\mathrm{b}} \mathrm{OBn}\right), 3.27-3.22(\mathrm{~m}, 1 \mathrm{H}$, $\mathrm{CH}_{\mathrm{a}} H_{\mathrm{b}} \mathrm{OBn}$ ), 2.89 (br s, $\left.1 \mathrm{H}, \mathrm{NH}\right), 2.61(\mathrm{~m}, 1 \mathrm{H}, \mathrm{C}(2) H), 2.41-2.31\left(\mathrm{~m}, 2 \mathrm{H}, \mathrm{C}(6) H_{2}\right), 1.43$ (s, 6H, $\left.2 \times \mathrm{CH}_{3}\right) ;{ }^{13} \mathrm{C} \mathrm{NMR}\left(\mathrm{CDCl}_{3}, 75 \mathrm{MHz}\right): \delta_{\mathrm{C}} 138.3,137.8,128.3,128.2,127.9,127.8,127.7,127.6$, 110.3, 84.5, 76.5, 75.7, 73.3, 72.6, 68.7, 58.9, 46.4, 26.9, 26.7; ESI-MS: m/z $384[\mathrm{M}+\mathrm{H}]^{+}$; HRMS (ESI): $m / z[\mathrm{M}+\mathrm{H}]^{+}$calcd for $\mathrm{C}_{23} \mathrm{H}_{30} \mathrm{NO}_{4}: 384.1742$, found: 384.1745 .

(+)-1-Deoxynojirimycin (1). A mixture of $19(383 \mathrm{mg}, 1 \mathrm{mmol})$ and $\mathrm{Pd} / \mathrm{C}$ (10\% content, 30\% $w t / w t, 115 \mathrm{mg})$ in EtOAc : $\mathrm{MeOH}(1: 1,10 \mathrm{~mL})$ having $0.5 \mathrm{~mL}$ of $6 \mathrm{~N} \mathrm{HCl}$ was stirred for $48 \mathrm{~h}$ at room temperature under $\mathrm{H}_{2}$ atmosphere (balloons). The catalyst was filtered through pad of celite, repeatedly washed with aqueous $\mathrm{MeOH}$ and the filtrate was concentrated in vacuo afforded a residue that was retained on a column packed with Dowex 50wx8 (200-400 mesh) ion-exchange resin. The column was washed with $\mathrm{MeOH}$, water and then with $5 \% \mathrm{NH}_{4} \mathrm{OH}$ to afford pure compound $1(121 \mathrm{mg}, 75 \%)$ as white solid; mp 199-202 ${ }^{\circ} \mathrm{C}$; $[\alpha]_{\mathrm{D}}{ }^{25}=+50(c 0.2$, 
$\left.\mathrm{H}_{2} \mathrm{O}\right)$, [lit. $\left.{ }^{20 \mathrm{~b}} \mathrm{mp} 202-204^{\circ} \mathrm{C},[\alpha]_{\mathrm{D}^{21}}=+47.1\left(c 0.17, \mathrm{H}_{2} \mathrm{O}\right)\right]$; IR $(\mathrm{KBr}):\left(v_{\max }, \mathrm{cm}^{-1}\right) 3316,2894$, 2837, 1374, 1101, 1042, 990; ${ }^{1} \mathrm{H}$ NMR $\left(\mathrm{D}_{2} \mathrm{O}, 300 \mathrm{MHz}\right): \delta_{\mathrm{H}} 3.82(\mathrm{dd}, J 2.8,11.7 \mathrm{~Hz}, 1 \mathrm{H}$, $\mathrm{CH}_{\mathrm{a}} \mathrm{H}_{\mathrm{b}} \mathrm{OH}$ ), $3.62\left(\mathrm{dd}, J 6.2,11.7 \mathrm{~Hz}, 1 \mathrm{H}, \mathrm{CH}_{\mathrm{a}} H_{\mathrm{b}} \mathrm{OH}\right.$ ), 3.49 (ddd, $J$ 5.0, 10.5, $14.1 \mathrm{~Hz}, 1 \mathrm{H}$, $\mathrm{C}(5) H), 3.31(\mathrm{t}, J 9.4 \mathrm{~Hz}, 1 \mathrm{H}, \mathrm{C}(3) H), 3.2(\mathrm{t}, J 9.4 \mathrm{~Hz}, 1 \mathrm{H}, \mathrm{C}(4) H), 3.11(\mathrm{dd}, J 5.0,12.4 \mathrm{~Hz}, 1 \mathrm{H}$ $\left.\mathrm{C}(6) H_{\mathrm{a}} \mathrm{H}_{\mathrm{b}}\right), 2.54(\mathrm{ddd}, J 2.8,6.2,9.4 \mathrm{~Hz}, 1 \mathrm{H}, \mathrm{C}(2) H), 2.46\left(\mathrm{t}, J 11.8 \mathrm{~Hz}, 1 \mathrm{H}, \mathrm{C}(6) \mathrm{H}_{\mathrm{a}} H_{\mathrm{b}}\right) ;{ }^{13} \mathrm{C}$ NMR $\left(\mathrm{D}_{2} \mathrm{O}, 100 \mathrm{MHz}\right): \delta_{\mathrm{C}} 81.0,74.1,73.4,63.9,63.1,51.3$; ESI-MS: $m / z 164[\mathrm{M}+\mathrm{H}]^{+} ; \mathrm{HRMS}$ (ESI): $m / z[\mathrm{M}+\mathrm{H}]^{+}$calcd for $\mathrm{C}_{6} \mathrm{H}_{14} \mathrm{NO}_{4}: 164.0922$, found: 164.0925 .

D-Glucono- $\delta$-lactam (5). A mixture of dihydroxy-azide compound $15 a(430 \mathrm{mg}, 1 \mathrm{mmol})$ and $\mathrm{Pd} / \mathrm{C}(10 \%$ content, $30 \% \mathrm{wt} / \mathrm{wt}, 130 \mathrm{mg})$ in EtOAc:MeOH $(1: 1,20 \mathrm{~mL})$ was stirred for $48 \mathrm{~h}$ at $\mathrm{rt}$ under $\mathrm{H}_{2}$ atmosphere (balloons). Filtration of the mixture, washing with $\mathrm{MeOH}(30 \mathrm{~mL})$, and evaporation gave only traces of $\mathbf{5}$. While washing the mixture with $\mathrm{H}_{2} \mathrm{O}(50 \mathrm{~mL})$, after evaporation, however afforded the crude compound $\mathbf{5}$ which was recrystallized from $\mathrm{H}_{2} \mathrm{O} / \mathrm{EtOH}$ to afford pure compound $5(142 \mathrm{mg}, 80 \%)$; white solid; mp: $203-205^{\circ} \mathrm{C}$; $[\alpha]_{\mathrm{D}}{ }^{25}=+54.3(c 0.5$, $\left.\mathrm{H}_{2} \mathrm{O}\right),\left\{\left[\right.\right.$ lit. ${ }^{20 \mathrm{a}} \mathrm{mp} 204-205^{\circ} \mathrm{C},[\alpha]_{\mathrm{D}}{ }^{20}=+57\left(c 0.63, \mathrm{H}_{2} \mathrm{O}\right] ;$ [lit. $^{21 \mathrm{~b}} \mathrm{mp} 205-207^{\circ} \mathrm{C},[\alpha]_{\mathrm{D}}{ }^{22}=+59(c$ $\left.\left.0.39, \mathrm{H}_{2} \mathrm{O}\right]\right\}$; IR $(\mathrm{KBr}):\left(v_{\max }, \mathrm{cm}^{-1}\right) 3423,3259,3177,2932,1648,1319,1127 ;{ }^{1} \mathrm{H}$ NMR $\left(\mathrm{D}_{2} \mathrm{O}\right.$, $400 \mathrm{MHz}$ ): $\delta_{\mathrm{H}} 3.98(\mathrm{~d}, J 8.8 \mathrm{~Hz}, 1 \mathrm{H}, \mathrm{C}(3) H), 3.80\left(\mathrm{dd}, J 3.2,12.0 \mathrm{~Hz}, 1 \mathrm{H}, \mathrm{CH}_{\mathrm{a}} \mathrm{H}_{\mathrm{b}} \mathrm{OH}\right), 3.73-3.67$ (m, 3H, $\left.\mathrm{CH}_{\mathrm{a}} H_{\mathrm{b}} \mathrm{OH}, \mathrm{C}(4) H, \mathrm{C}(5) H\right), 3.36-3.30(\mathrm{~m}, 1 \mathrm{H}, \mathrm{C}(6) H) ;{ }^{13} \mathrm{C}$ NMR $\left(\mathrm{D}_{2} \mathrm{O}, 75 \mathrm{MHz}\right): \delta_{\mathrm{C}}$ 173.3, 73.2, 70.6, 67.5, 60.3, 56.9; ESI-MS: $m / z 200[\mathrm{M}+\mathrm{Na}]^{+}$; HRMS (ESI): $m / z[\mathrm{M}+\mathrm{Na}]^{+}$calcd for $\mathrm{C}_{6} \mathrm{H}_{11} \mathrm{NO}_{5} \mathrm{Na}$ : 200.0534, found: 200.0538 .

D-Altrono- $\boldsymbol{\delta}$-lactam (6). The title compound $\mathbf{6}$ was prepared from $\mathbf{1 5 b}$ according to the procedure described for the synthesis of $\mathbf{5}$ from 15a. Yield: $138 \mathrm{mg}$, (78\%); white solid; mp 136$138{ }^{\circ} \mathrm{C} ;[\alpha]_{\mathrm{D}}{ }^{25}=-28.8\left(c 0.35, \mathrm{H}_{2} \mathrm{O}\right)$, [lit. $\left.{ }^{21 \mathrm{~b}} \mathrm{mp} 141-143{ }^{\circ} \mathrm{C},[\alpha]_{\mathrm{D}}{ }^{26}=-33.7\left(c 0.30, \mathrm{H}_{2} \mathrm{O}\right)\right] ;$ IR $(\mathrm{KBr}):\left(v_{\max }, \mathrm{cm}^{-1}\right) 3420,3257,3272,2937,1654,1322,1125 ;{ }^{1} \mathrm{H}$ NMR $\left(\mathrm{D}_{2} \mathrm{O}, 400 \mathrm{MHz}\right): \delta_{\mathrm{H}}$ $4.19(\mathrm{~d}, J 8.7 \mathrm{~Hz}, 1 \mathrm{H}, \mathrm{C}(3) H), 4.15(\mathrm{t}, J 2.9 \mathrm{~Hz}, 1 \mathrm{H}, \mathrm{C}(4) H), 4.01(\mathrm{dd}, J 2.9,8.7 \mathrm{~Hz}, 1 \mathrm{H}, \mathrm{C}(5) H)$, $3.68\left(\mathrm{dd}, J 5.1,11.7 \mathrm{~Hz}, 1 \mathrm{H}, \mathrm{CH}_{\mathrm{a}} \mathrm{H}_{\mathrm{b}} \mathrm{OH}\right), 3.64\left(\mathrm{dd}, J 5.1,11.7 \mathrm{~Hz}, 1 \mathrm{H}, \mathrm{CH}_{\mathrm{a}} H_{\mathrm{b}} \mathrm{OH}\right), 3.56(\mathrm{dd}, J$ $5.1,8.7 \mathrm{~Hz}, 1 \mathrm{H}, \mathrm{C}(6) H) ;{ }^{13} \mathrm{C}$ NMR $\left(\mathrm{D}_{2} \mathrm{O}, 75 \mathrm{MHz}\right): \delta_{\mathrm{C}} 173.8,70.5,69.8,67.9,62.7,57.9$; ESIMS: $m / z 200[\mathrm{M}+\mathrm{Na}]^{+}$; HRMS (ESI): $\mathrm{m} / z[\mathrm{M}+\mathrm{Na}]^{+}$calcd for $\mathrm{C}_{6} \mathrm{H}_{11} \mathrm{NO}_{5} \mathrm{Na}: 200.0534$, found: 200.0528

\section{Acknowledgements}

The authors thank the Director, IICT for encouragement. This work is the Main Lab Project of IICT. MR thanks CSIR, New Delhi; TNR and BM thanks UGC, New Delhi for fellowships. 


\section{References}

1. For recent reviews on the synthesis of polyhydroxylated piperidines and other imino sugars see: (a) Pearson, M. S. M.; Mathé-Allainmat, M.; Fargeas, V.; Lebreton, J. Eur. J. Org. Chem. 2005, 2159. (b) Afarinkia, K.; Bahar, A. Tetrahedron: Asymmetry 2005, 16, 1239. (c) Yoda, H.; Curr. Org. Chem. 2002, 6, 223. (d) Lillelund, V. H.; Jensen, H. H.; Liang, X.; Bols, M. Chem. Rev. 2002, 102, 515.

2. (a) Watson, A. A.; Fleet, G. W. J.; Asano, N.; Molyneux, R. J.; Nash, R. J. Phytochemistry 2001, 56, 265. (b) Asano, N.; Nash, R. J.; Molyneux, R. J.; Fleet, G. W. J. Tetrahedron: Asymmetry 2000, 11, 1645. (c) Simmonds, M. S. J.; Kite, G. C.; Porter, E. A, Taxonomic Distribution of Iminosugars in Plants and Their Biological Activities. Stütz, A. E., Ed.; Wiley-VCH: Weinheim, 1999; pp 8-30.

3. (a) Iminosugars as Glycosidase Inhibitors. Nojirimycin and Beyond; Stütz, A. E., Ed.; Wiley-VCH: Weinheim, 1999. (b) Look, G. C.; Fotsch, C. H.; Wong, C.-H. Acc. Chem. Res. 1993, 26, 182. (c) Bols, M. Acc. Chem. Res. 1998, 31, 1. (d) Zechel, D. L.; Withers, S. G.; Acc. Chem. Res. 2000, 33, 11.

4. (a) Robinson, K. M.; Begovic, M. E.; Rhinehart, B. L.; Heineke, E. W.; Ducep, J.-B.; Kastner, P. R.; Marshall, F. N.; Danzin, C. Diabetes 1991, 40, 825. (b) Alper, J. Science 2001, 291, 2338. (c) Nishimura, Y. Curr. Top. Med. Chem. 2003, 3, 575 and references therein. (d) Greimel, P.; Spreitz, J.; Stutz, A. E.; Wrodnigg, T. M. Curr. Top. Med. Chem. 2003, 3, 513. (e) Taylor, D. L.; Sunkara, P.; Liu, P. S.; Kang, M. S.; Bowlin, T. L.; Tyms, A. S. AIDS 1991, 5, 693. (f) Asano, N.; Ishii, S.; Kizu, H.; Ikeda, K.; Yasuda, K.; Kato,A.; Martin, O. R.; Fan, J. Q. Eur. J. Biochem. 2000, 267, 4179. (g) Asano, N. Glycobiology, 2003, 13, 93R. (h) Wrodnigg, T. M.; Sprenger. F. K. Mini-Rev. Med. Chem. 2004, 4, 437.

5. (a) Mitrakou, A.; Tountas, N.; Raptis, A. E.; Bauer, R. J.; Schulz, H.; Raptis, S. A. Diabetic Med. 1998, 15, 657. (b) Cox, T.; Lachmann, R.; Hollack, C.; Aerts, J.; van Weely, S.; Hrebicek, M.; Platt, F. M.; Butters, T. D.; Dwek, R.; Moyses, C.; Gow, L.; Elstein, D.; Zimran, A. Lancet 2000, 355, 1481. (c) Butters, T. D.; Dwek, R. A.; Platt, F. M. Curr. Top. Med. Chem. 2003, 3, 561.

6. For previous syntheses of the deoxynojirimycin family see: (a) Wang, G-N.; Xiong, Y.; Ye, J.; Zhang, L-H.; Ye, X-S. Med. Chem. Lett. 2011, 2, 682. (b) Bagal, S. K.; Davies, S. G.; Lee, J. A.; Roberts, P. M.; Scott, P. M.; Thmson, J. E. J. Org. Chem. 2010, 75, 8133 and references therein. (c) Jadhav, V. H.; Bande, O. P; Puranik, V. G.; Dhavale, D. D. Tetrahedron: Asymmetry 2010, 21, 163. (d) Best, D., Wang, C.; Weymouth-Wilson, A. C.; Clarkson, R. A.; Wilson, F. X.; Nash, R. J.; Miyauchi, S.; Kato, A.; Fleet, G. W. J. Tetrahedron: Asymmetry 2010, 21, 311. (e) Karjalainen, O. K.; Passiniemi, M.; Koskinen, A. M. P. Org. Lett. 2010, 12, 1145. (f) Zhou, Y.; Murphy, P. V. Org. Lett. 2008, 10, 3777 and references therein. (g) Ruiz, M.; Ruanova, T. M.; Blanco, O.; Núñez, F.; Pato, C.; Ojea, V. J. Org. Chem. 2008, 73, 2240 and references therein. (h) Lenagh-Snow, G. M. J.; Jenkinson, S. F.; Newberry, S. J.; Kato, A.; Nakagawa, S.; Adachi, I.; Wormald, M. R.; 
Yoshihara, A.; Morimoto, K.; Akimistu, K.; Lzumori, K.; Fleet, G. W. J. Org. Lett. 2012, 14, 2050.

7. (a) Ravinder, M.; Sadhu, P. S.; Jayathirtha Rao, V. Tetrahedron Lett. 2009, 50, 4229. (b) Ravinder, M.; Sadhu, P. S.; Santhoshi, A.; Narender, P.; Swamy, G. Y. S. K.; Ravikumar, D.; Jayathirtha Rao, V. Synthesis 2010, 573. (c) Ravinder, M.; Mahendar, B.; Saidulu, M.; Venkata Hamsini, K.; Narendar Reddy, T.; Rohit, C.; Sanjay Kumar, B.; Jayathirtha Rao, V. Bioorg. Med. Chem. Lett. 2012, 22, 6010.

8. (a) Srinivas, C.; Pavan Kumar, C. N. S. S.; China Raju, B.; Jayathirtha Rao, V.; Naidu, V. G. M.; Ramakrishna, S.; Diwan, P. V. Bioorg. Med. Chem. Lett. 2009, 19, 5915. (b) Kumar, P. A.; Raman, D.; Murthy, U. S. N.; Jayathirtha Rao, V. Syn. Commun. 2010, 40, 686. (c) Ravinder. M.; Narendar Reddy, T.; Oladoye, S. O.; Ramesh, V.; Jayathirtha Rao, V. Arkivoc 2012, (vi), 421.

9. (a) Sugiyama, T.; Sugawara, H.; Watanabe, M.; Yamashita, K. Agric. Biol. Chem. 1984, 48, 1841. (b) Chattopadhyay, A.; Mamdapur, V. R. J. Org. Chem. 1995, 60, 585. (c) Pavan Kumar, C. N. S. S.; Ravinder, M.; Naveen Kumar, S.; Jayathirtha Rao, V. Synthesis 2011, 451.

10. (a) Katsuki, T.; Sharpless, K. B. J. Am. Chem. Soc. 1980, 102, 5974. (b) Gao, Y.; Hanson, R. M.; Klunder, J. M.; Ko, S. Y.; Masamune, H.; Sharpless, K. B. J. Am. Chem. Soc. 1987, 109, 5765. (c) Kagawa, N.; Ihara, M.; Toyota, M. Org. Lett. 2006, 8, 875.

11. (a) Sasaki, M.; Tanino, K.; Hirai, A., Miyashita, M. Org. Lett. 2003, 5, 1789. (b) Rogers, E. W.; Molinski, T. F. J. Org. Chem. 2009, 74, 7660.

12. Kim, Y. J.; Ichikawa, M.; Ichikawa, Y. J. Org. Chem. 2000, 65, 2599.

13. Blanchette, M. A; Choy, W.; Davis, J. T.; Essenfeld, A. P.; Masamune, S.; Roush, W. R.; Sakai, T. Tetrahedron Lett. 1984, 25, 2183.

14. (a) Kolb, H. C.; VanNieuwenhze, M. S.; Sharpless, K. B. Chem. Rev. 1994, 94, 2483. (b) Zaitsev, A.; Adolfsson, H. Synthesis 2006, 1725.

15. Walsh, P. J.; Sharpless, K. B. Synlett 1993, 605.

16. Van Rheenen, V.; Kelly, R. C.; Cha, D. Y. Tetrahedron Lett. 1976, 17, 1973.

17. Becker, H.; Sharpless, K. B. Angew. Chem. Int. Ed. Engl. 1996, 35, 448.

18. (a) Imashiro, R.; Sakurai, O.; Yamashita, T.; Horikawa, H. Tetrahedron 1998, 54, 10657. (b) Yoon, H. J.; Kim, Y.-W.; Lee, B. K.; Lee, W. K.; Kim, Y.; Ha, H.-J. Chem. Commun. 2007, 79.

19. Brown, H. C.; Narasimhan, S. J. Org. Chem. 1982, 47, 1604.

20. (a) Fleet, G. W. J.; Carpenter, N. M.; Petursson, S.; Ramsden, N. G. Tetrahedron Lett. 1990, 31, 409. (b) Iida, H.; Yamazaki, N.; Kibayashi, C. J. Org. Chem. 1987, 52, 3337.

21. (a) Overkleeft, H. S.; Wilternburg, J. M.; Pandit, U. K. Tetrahedron 1994, 50, 4215. (b) Nishimura, Y.; Adachi, H.; Satoh, T.; Shitra, E.; Nakamura, H.; Kojima, F.; Takeuchi, T. J. Org. Chem. 2000, 65, 4871. 